\title{
Recent insights for the emerging COVID-19: drug discovery, therapeutic options and vaccine development
}

\author{
Yuefei $\mathrm{Zhu}^{1}$, Jia $\mathrm{Li}^{2}$, and zhiqing pang ${ }^{3}$ \\ ${ }^{1}$ Columbia University Medical Center \\ ${ }^{2}$ Macquarie University \\ ${ }^{3}$ Fudan University
}

April 29, 2020

\begin{abstract}
SARS-CoV-2 has been marked as a highly pathogenic coronavirus of COVID-19 disease into the human population, causing over 2.8 million confirmed cases worldwide. As COVID-19 has posed a global threat with significant human casualties and severe economic losses, there is a pressing demand to further understand the current situation and develop rational strategies to contain the drastic spread of the virus. Although there are no specific antiviral therapies that have proven effective in randomized clinical trials, currently, the rapid detection technology along with several promising therapeutics for COVID-19 have mitigated its drastic transmission. Besides, global institutions and corporations have commenced to parse out effective vaccines for the prevention of COVID-19. Herein, the present review will give exhaustive details of extensive researches concerning the drug discovery and therapeutic options for COVID-19 as well as some insightful discussions of the status of COVID-19.
\end{abstract}

\begin{abstract}
SARS-CoV-2 has been marked as a highly pathogenic coronavirus of COVID-19 disease into the human population, causing over 2.8 million confirmed cases worldwide. As COVID-19 has posed a global threat with significant human casualties and severe economic losses, there is a pressing demand to further understand the current situation and develop rational strategies to contain the drastic spread of the virus. Although there are no specific antiviral therapies that have proven effective in randomized clinical trials, currently, the rapid detection technology along with several promising therapeutics for COVID-19 have mitigated its drastic transmission. Besides, global institutions and corporations have commenced to parse out effective vaccines for the prevention of COVID-19. Herein, the present review will give exhaustive details of extensive researches concerning the drug discovery and therapeutic options for COVID-19 as well as some insightful discussions of the status of COVID-19.
\end{abstract}

Key word: coronavirus, COVID-19, SARS-CoV-2, precise prevention and control, drug discovery, vaccine development

\section{Introduction}

This century has witnessed the worldwide spread of several hitherto unknown coronaviruses. The rapid alteration of ecology and urbanization along with vulnerable public health systems have facilitated more frequent emerging of epidemics, which have become more and more intractable for us to prevent and contain. In December 2019, a new coronavirus correlated with human respiratory disease was firstly reported causing pneumonia and death (Chan et al., 2020b). Soon afterward, the disease cases continued to expand and soared dramatically worldwide. The causative virus, named as SARS-CoV-2, was identified as the pathogen leading to the coronavirus disease COVID-19. Infections with SARS-CoV-2 are now swift and violent, and 
as of 26 April 2020, over 2.8 million cases have been confirmed in more than 207 countries, with over 193,825 deaths. To date, SARS-CoV-2 has most closest relation to SARS and relevant viruses that circulate in bats, as evidenced by viral genome analysis as well as the research probing into the proximal origin of such virus (Andersen et al., 2020).

In general, coronaviruses (CoVs), subfamily Coronavirinae, are a cluster of highly diversified, enveloped, positive-sense, single-stranded viruses ((+)ssRNA virus) that can induce enteric, respiratory, hepatic as well as neurological disorders of discrepant severity in a wide range of animal species, encompassing humans (Chan et al., 2013; Zumla et al., 2016). As the largest RNA viruses ever discovered, CoVs can be categorized into $\alpha-, \beta-, \delta$ - and $\gamma$-coronaviruses. Among these genera, the $\beta$ group can be subdivided into A, B, C, and D lineages (Xia et al., 2020b). In the past 17 years, three neoteric $\beta$-CoVs, severe acute respiratory syndrome $\mathrm{CoV}$ (SARS-CoV), Middle East respiratory syndrome CoV (MERS-CoV), along with SARS-CoV-2 have emerged, engendering severe human diseases. Although the origin of the SARS-CoV-2 outbreak is not yet clear, recent studies have deduced that it might be transmitted through bats because it is highly similar to the bat SARS-CoV-like coronaviruses (Zhou et al., 2020b). Later on, genomic and evolutionary proofs of the occurrence of Pangolin-CoV indicated that pangolin species might be the potential intermediate host for SARS-CoV-2 (Cyranoski, 2020; T. Zhang et al., 2020). Unlike human coronaviruses, zoonotic viruses hold the capacity of infecting both animals and humans, leading to severe respiratory diseases (i.e., acute respiratory distress syndrome (ARDS) and pneumonia)(Graham et al., 2013; Peiris et al., 2003). Clinical data revealed that the COVID-19 symptoms are far more severe among the elders with comorbidities, while asthma, allergic illnesses, as well as chronic obstructive pulmonary disease are also risk factors (X. Yang et al., 2020; J. Zhang et al., 2020). Despite the continuous improvement of the prevention strategy and the disease surveillance system, the lack of efficacious drug treatment and correlated high morbidity cases of the SARS-CoV-2 along with its potentiality to induce pandemics, highlighting the urgent demand for neoteric drug discovery. In this review, we will first briefly describe the status of epidemiology, mechanism, and diagnosis of COVID-19. In addition to the discussion of current management strategies for COVID-19, the emphasis has been given to the treatment options and drug discovery of COVID-19. We will refer to the drug screening progress and the development of vaccines for the COVID-19 therapy. Ultimately, we will delineate the overarching challenges in the clinical invention of new anti-coronavirus agents and offer some insights toward the prevention of such disease based on the understanding of its epidemic dynamics in real-time.

\section{The epidemiology of COVID-19}

Spread mainly through respiratory droplets or close contact, SARS-CoV-2 induced diseases has been growing dramatically in accordance with the published data from the World Health Organization (WHO) (Organization, 2020). Although the number of confirmed cases in China has decreased a lot from late February 2020, and there is no report of COVID-19 deaths on 6 April, the confirmed cases of coronavirus worldwide are still expanding with a vengeance. The spectrum of illness presentation or severity profile also affects triage and diagnostic decision-making, along with the therapeutic options and prognostic expectations (Wu et al., 2020c). Till now, the exact source of the current outbreak of COVID-19 remains unclear, but the dynamic model is similar to the classic zoonotic emergence to human-to-human transmission (Metcalf and Lessler, 2017). The mortality rate of SARS-CoV-2 $(\sim 3.8 \%)$ is lower compared to that of MERS-CoV $(37.1 \%)$ or SARS-CoV (10\%), but the number of infections is more than ten times higher (Ahn et al., 2020). With respect to the lack of evidence that companion animals might be a source of infection, patients with COVID19 are the prime source of infection, and those with severe conditions are more infectious than those with mild conditions. Intriguingly, asymptomatically infected persons or patients in incubation has also been demonstrated to shed the infectious virus, serving as a potential infection source to drive the transmission of the COVID-19 (Hoehl et al., 2020). In addition, researches focused on the follow-up of recovered patients revealed that the tested samples of rehabilitees continuously showed a positive RT-PCR result, implicating that asymptomatic infection during incubation or recovery from COVID-19 may pose a daunting challenge to disease control and prevention (Lan et al., 2020).

The incubation period refers to the time between exposure to the virus and initial symptoms. A research 
report on the early propagation dynamics of COVID-19 unveiled that the average incubation period of COVID-19 was around 5 days, and its $95 \%$ distribution was 12.5 days ( $\mathrm{Li}$ et al., 2020). Another study analyzing the travel history and symptoms in 88 confirmed cases revealed a similar average incubation period of around 6 days (Backer et al., 2020). In addition, there was an unusual case with an incubation period of up to 19 days (Bai et al., 2020). Although such a long incubation period may be a low probability event (the condition of 14 days was suggested by experts for quarantine), the longer incubation time indicates the adjustment of screening and control policies (Jiang et al., 2020).

The early outbreak data of COVID-19 largely follow exponential growth. Disparate models based upon the clinical progression of the disease had been proposed to assess the basic reproductive ratio $\mathrm{R}_{0}$. A retrospective analysis of the first 425 identified cases demonstrated that in the early stages of COVID-19, the $\mathrm{R}_{0}$ was assessed to be 2.2 ( $\mathrm{Li}$ et al., 2020). Nevertheless, deterministic compartmental models based upon the likelihood and a model analysis revealed that the control reproduction number $\mathrm{R}_{\mathrm{c}}$ might be as high as 6.5 due to the estimation of four generations of viral transmission and serried social contacts (Tang et al., 2020). In this regard, it is noteworthy that $R_{0}$ estimates may vary in the light of numerous biologics, social behavior, and environmental factors (Delamater et al., 2019). In general, the basic $\mathrm{R}_{0}$ assessed by the majority of researches ranges between 2 to 4 (Lai et al., 2020). According to the WHO data updated on April 26, 2020, more than 200 countries have reported 2,810,325 confirmed cases, including 193,825 deaths (Figure 1). The grand total case fatality rate of global cases outside China is $2.39 \%$ (WHO, 2020). The US had also recorded the largest number of coronavirus deaths in a day, with more than 1,810 deaths reported on April 7, according to data from Johns Hopkins University. Given the condition that the population of all races and ages is generally susceptible, there is an urgent need to further implementing the timely diagnosis, along with efficient isolation of patients, to cut down the $\mathrm{R}_{0}$ of SARS-CoV-2 and control the epidemic outbreak.
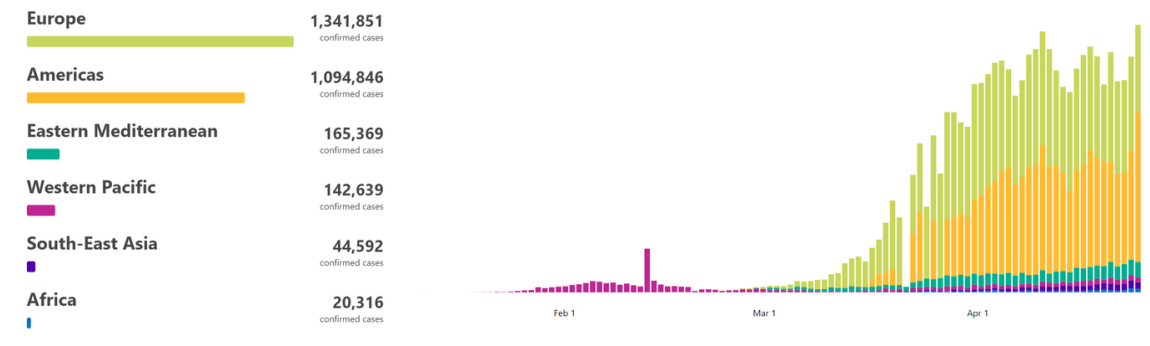

Figure 1. Cumulatively identified cases of COVID-19 worldwide, as of 26 April, 2020 (WHO, 2020).

\section{Virological characteristics of SARS-CoV-2}

As previously mentioned, SARS-CoV-2, belonging to the coronaviridae family, is the causative pathogen of COVID-19. Closely resembled other $\beta$-CoVs, the SARS-CoV-2 virion with a genome size of $\sim 3 \mathrm{~kb}$ has a nucleocapsid consisted of genomic RNA and phosphorylated nucleocapsid (N) protein (Jin et al., 2020). Of note, the nucleocapsid is embedded in a phospholipid bilayer and is encased by two disparate types of spike proteins: spike glycoprotein trimmer present in all coronaviruses and the hemagglutinin-esterase shared merely in some CoVs. The spike (S) protein plays a pivotal role in binding to receptors and is the key to determine host tropism and transmission capacity (Figure 2). The matrix protein (M) along with the viral envelop (E) are also located in the viral envelope (Wu et al., 2020b). Genome analysis showed that the SARS-CoV-2 possesses 5' and 3' terminal sequences, with a gene order 5' -replicase open reading frame (ORF) 1ab-S-envelope(E)-membrane(M)-N-3' (Lu et al., 2020). The virus particle is $60^{\sim} 100 \mathrm{~nm}$ in diameter and are round or oval (Xia et al., 2020a). It can be inactivated by ultraviolet light or heated at $56{ }^{\circ} \mathrm{C}$ for $30 \mathrm{~min}$ and is sensitive to most disinfectants (i.e., ether, $75 \%$ ethanol, peracetic acid, chlorine, as well as chloroform) (Kratzel et al., 2020). 


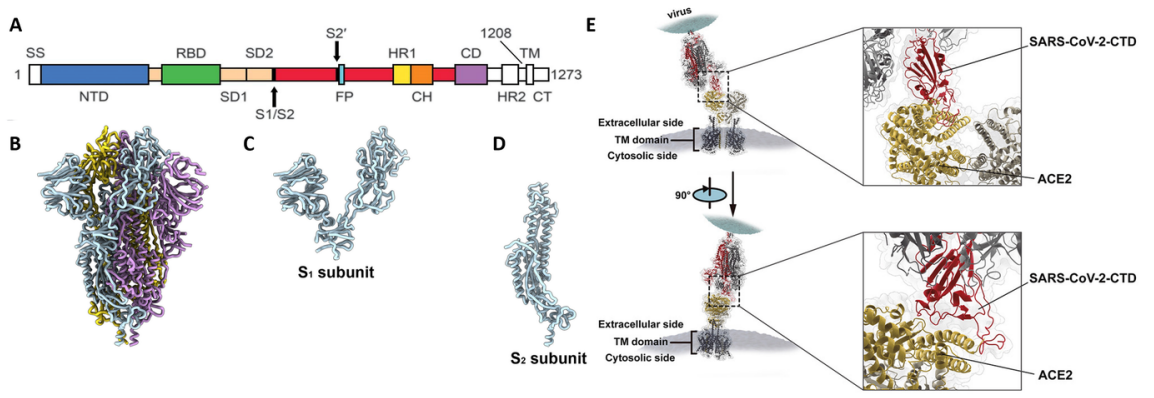

Figure 2. Structure of SARS-CoV-2 $\mathrm{S}$ in the pre-fusion conformation and the genome, along with the crystal structure of the C-terminal domain of SARS-CoV-2 (SARS-CoV-2-CTD) S protein in complex with human ACE2. (A) Schematic of SARS-CoV-2 S primary structure colored by domain. (B) Ribbon diagrams of the SARS-CoV-2 S ectodomain cryoEM structures. (C) The SARS-CoV-2 S1 subunits. (D) The SARS-CoV-2 S2 subunits. (E) A hACE2-binding mode of SARS-CoV-2. Reproduced with permission (Wrapp et al., 2020; Walls et al., 2020; Q. Wang et al., 2020).

Accumulating evidence has revealed that SARS-CoV-2 and SARS-CoV have the same human cell receptor, the angiotensin-converting enzyme 2 (ACE2), while MERS-CoV hinges on dipeptidyl peptidase 4 for host cell entry (Wan et al., 2020). ACE2 is a type I membrane protein expressed in the lungs, hearts, kidneys, and intestines, mainly associated with cardiovascular diseases (Wan et al., 2020). A recent study analyzed the cryogenic electron microscopy structure of the SARS-CoV-2 S protein unveiled that it exhibits around 10 to 20-fold higher binding affinity to ACE2 in comparison with SARS-CoV (Berry et al., 2004). The overall replication cycle of SARS-CoV-2 is depicted in the following Figure 3.

As for the phylogenetic network analysis of SARS-CoV-2 genomes, after analysis of the sample from across the world, researchers have found three central variants differentiated through amino acid alterations, denoted $\mathrm{A}, \mathrm{B}$, and $\mathrm{C}$, with $\mathrm{A}$ being the ancestral type in line with the bat outgroup $\mathrm{CoV}$. Intriguingly, types $\mathrm{A}$ and $\mathrm{C}$ account for a considerable proportion outside East Asia ( Europe and the United States) (Forster et al., 2020). By comparison, B is the most common type in East Asia, and its ancestors 'genomes do not appear to spread outside East Asia without first mutating into a derived type B. Hence, SARS-CoV-2 genomes were found to be closely correlated, and evolutionary selection took place in human hosts, sometimes with parallel evolutionary events, where the same viral mutation occurs in two disparate human hosts (Forster et al., 2020). Owing to the erratic nature of RNA viruses as well as its high contagiousness, the continuous monitoring of SARS-CoV-2 from humans or animal species is of extreme significance for pandemic control. 


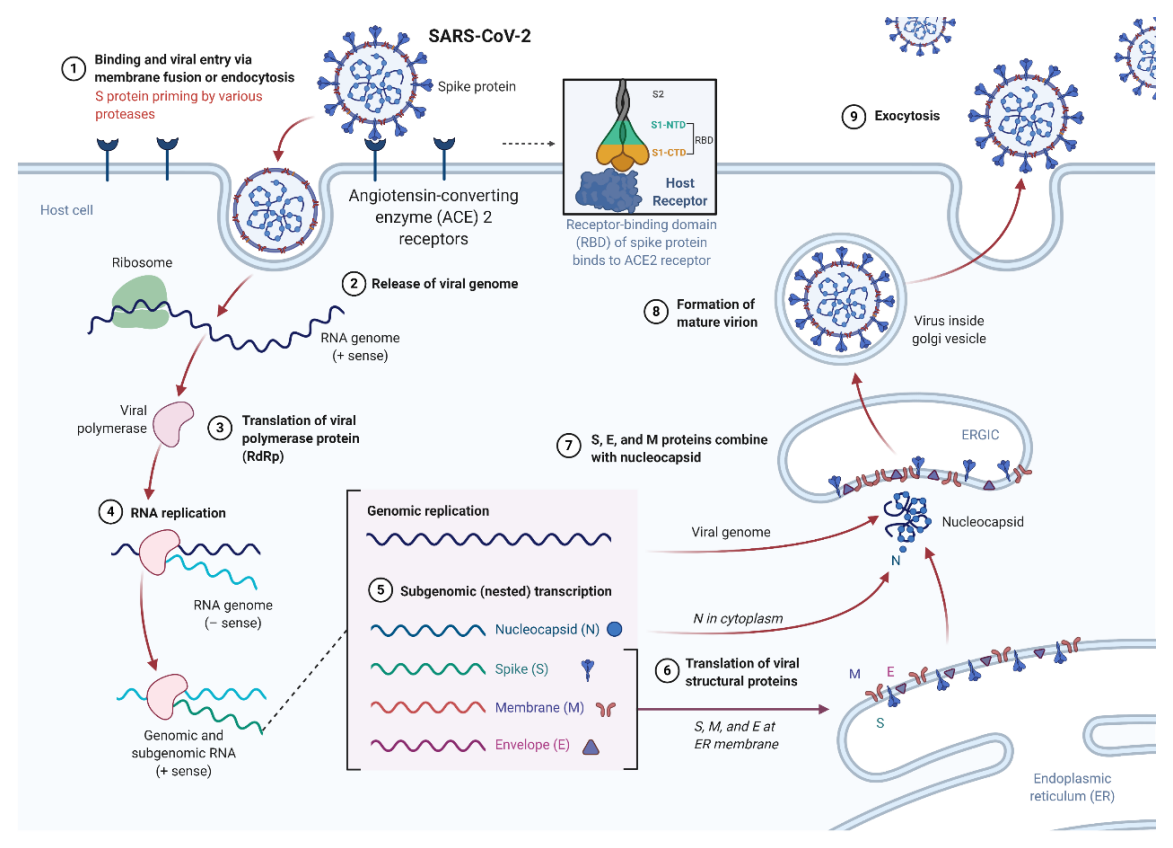

Figure 3. The possible viral entry and replication mechanism of SARS-CoV-2.

1. Diagnosis and Pathogenesis of SARS-CoV-2

2. Diagnostic testing for COVID-19

Rapid and accurate diagnosis of COVID-19 is of considerable significance for controlling outbreaks in the communities and hospitals (To et al., 2020). Technologies such as polymerase chain reaction (PCR), reversetranscription polymerase chain reaction (RT-PCR), real-time RT-PCR (rRT-PCR), and reverse transcription loop-mediated isothermal amplification (RT-LAMP) have been leveraged as ideal diagnostic tests for coronaviruses (Chan et al., 2015; Bhadra et al., 2015). To date, the frontline reaction to the SARS-CoV-2 outbreak has been PCR testing. As the gold standard for diagnosing the source of infection, PCR holds the preponderance that the primers required for such assays can be generated relatively quickly once the viral sequence is identified (Figure 4) (Sheridan, 2020). Soon after the virus was identified, the first quantitative RT-PCR assays to detect SARS-CoV2 were inaugurated and distributed in January 2020 by WHO. Nevertheless, this test protocol was complicated and high-priced, and is primarily applicable for large centralized diagnostic laboratories. As for the diagnostic criteria currently formulated by the China National Health Commission, nasopharyngeal cancer and oropharyngeal swab tests have ripened into the standard evaluation for the diagnosis of COVID-19 infection. So far, three new RT-PCR tests targeting the RNA-dependent RNA polymerase (RdRp)/helicase (Hel), nucleocapsid, and spike genes of SARS-CoV-2 had been inaugurated, with extremely lower detection limit in vitro(Chan et al., 2020a). The SARS-CoV E gene detection was superior to the RdRp gene test combined with the one-step RT-PCR system. The E gene PCR was adequate for diagnosing SARS-CoV-2 infection, but the RdRp protocol was endorsed to verify positive results (Corman et al., 2020). Remarkably, a new FDA-authorized COVID-19 test using the Abbott ID NOW diagnostics platform has been developed, which can produce results in just 5 minutes, cutting down on wait times both in terms of getting tested and receiving a diagnosis. As gene detection of SARS-CoV-2 might provide false negative results, it can be complemented by antibody detection, especially to better screen asymptomatic patients.

Clinically, for those who are recently suffering from fever, fatigue, sore throat, cough, or dyspnea due to exposure, the diagnosis of COVID-19 infection should be conducted with typical chest computerized tomography (CT) characteristics regardless of negative RT-PCR outcomes (Xie et al., 2020). 
Most of the COVID-19 cases shared similar characteristics on CT images, presenting bilateral distribution of patchy shadows and ground-glass opacity, sometimes presenting a circular shape and peripheral lung distribution (Kanne, 2020). Some of the data published from China showed that in 21 primal chest CT scans, a large proportion of patients $(86 \%)$ developed frosted glass opacity, affecting more than one lung lobe $(71 \%)$ (bilateral involvement) (Chung et al., 2020). It is also worth noting that lung cavitation, pleural effusions, discrete pulmonary nodules, along with lymphadenopathy were absent (Chung et al., 2020). In addition to imaging technology, a recent study displayed that the Cas13-based SHERLOCK (specific highsensitivity enzymatic reporter unlocking) platform can be harnessed for diagnosis of SARS-CoV-2 (Broughton et al., 2020.). However, such a system needs to be further verified in clinical tests. Overall, combined with immunochromatography, colloidal gold, and other biotechnologies, associative detection strategies have been progressed swiftly.
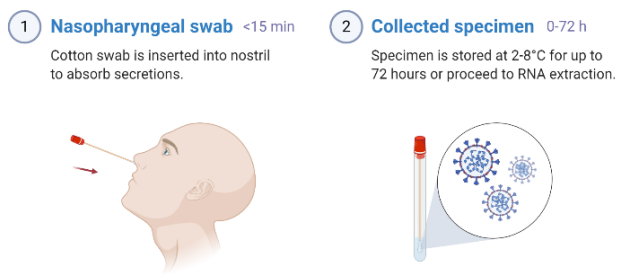

(3) RNA extraction $\sim 45 \mathrm{~min}$ Purified RNA is extracted from deactivated virus
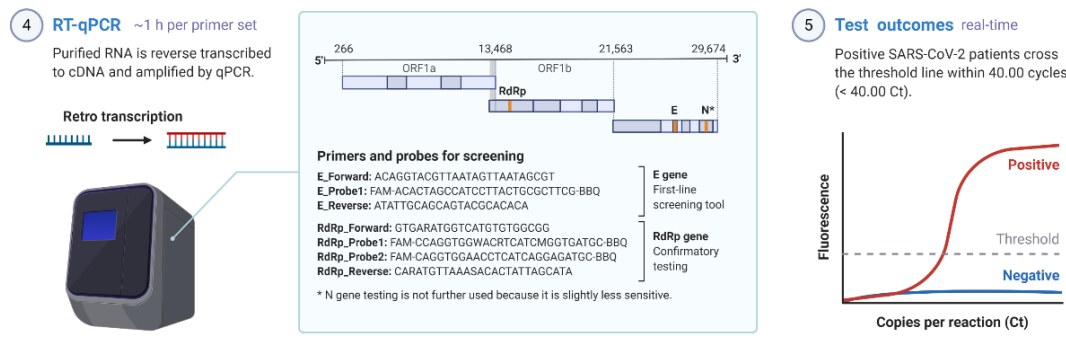

Figure 4. COVID-19 diagnostic test by RT-PCR.

\subsection{Pathogenesis of SARS-CoV-2}

With regard to the transmission of SARS-CoV-2, primary viral replication is assumed to occur in the mucosal epithelium of the upper respiratory tract and further multiplicated in the lower respiratory tract and gastrointestinal mucosa, inducing a mild viremia (Xiao et al., 2020). At this point, very few infections are under control and remain asymptomatic. Some patients may also suffer non-respiratory symptoms (i.e., acute liver and heart injury, renal failure, diarrhea), suggesting multiple organ involvement (Huang et al., 2020; D. Wang et al., 2020). Since ACE2 is extensively expressed in the nasal mucosa, bronchus, lung, heart, and kidney, etc., many human organs are vulnerable to SARS-CoV-2 (Zou et al., 2020). Specifically, the S protein plays a critical role in determining the cell tropism and hence interspecies transmission of SARS$\mathrm{CoV}-2$ since it hitches the virus to a cellular receptor and subsequently prompts virus entry via membrane fusion (Wrapp et al., 2020). After binding to the receptor, the spike protein can catalyze the viral fusion process, allowing the viral genome to enter the cytoplasm. A prerequisite for this procedure is the division of $\mathrm{S}$ to subunits, a process known as priming (Figure 3). The work of Hoffmann et al. unraveled that SARS-CoV-2 utilizes the ACE2 receptor for entry and the serine protease TMPRSS2 for S protein priming (Hoffmann et al., 2020). Hence, TMPRSS2 inhibitors approved for clinical use may block the entrance and may give rise to an underlying treatment option. Notably, the ability that $\mathrm{S}$ can readily obtain new protease cleavage sites and the fact that miscellaneous proteases can perform the same task suggests that this virus can easily adapt to the proliferation in several cell types (Walls et al., 2020). Further, a panel of murine monoclonal antibodies (mAbs) and polyclonal antibodies (pAbs) against SARS-CoV-S1/receptor- 
binding domain (RBD) had been reported to be unable to interplay with $\mathrm{S}$ protein, implicating conspicuous discrepancies in antigenicity between SARS-CoV-2 and SARS-CoV (Wang et al., 2020c).

According to the pathological findings, the first report on the pathological results of severe COVID-19 revealed that diffuse alveolar injury on both sides of the lung was accompanied by cellular fibromyxoid exudates (Xu et al., 2020). The right lung displayed significant lung cell shedding and hyaline membrane formation, suggesting ARDS. Moreover, the left lung tissue showed pulmonary edema and hyaline membrane formation, implying early ARDS. Interstitial mononuclear inflammatory infiltrates, dominated by lymphocytes, were found in both lungs. Another study reported that acute kidney injury and proteinuria might also occur during the progression of COVID-19 disease. ACE2 was seen to be upregulated in COVID-19 patients, and immunostaining with the SARS-CoV nucleoprotein antibody was positive in tubules (Su et al., 2020). Additionally, only a few interstitial mononuclear inflammatory infiltrates were found in the heart tissue, meaning that this virus may not directly induce heart impairment (Xu et al., 2020). Aside from the acute respiratory distress syndrome, exuberant inflammatory responses during the infection process were also observed in clinical, giving rise to unrestrained pulmonary inflammation. Of note, the virus-induced ACE2 downregulation, rapid virus replication and cell damage, and antibody-dependent enhancement may lead to aggressive inflammation aroused by SARS-CoV-2 (Fu et al., 2020). The initial stage of rapid viral replication would induce a large number of epithelial and endothelial cell death, thereby facilitating the generation of raging pro-inflammatory cytokines and chemokines (Figure 5) (Yang, 2020). In addition to the cytokine storm, several experimentations had unraveled that lymphopenia is a customary characteristic of COVID-19, which may also accounts for severity and mortality (Huang et al., 2020; Zhu et al., 2020).

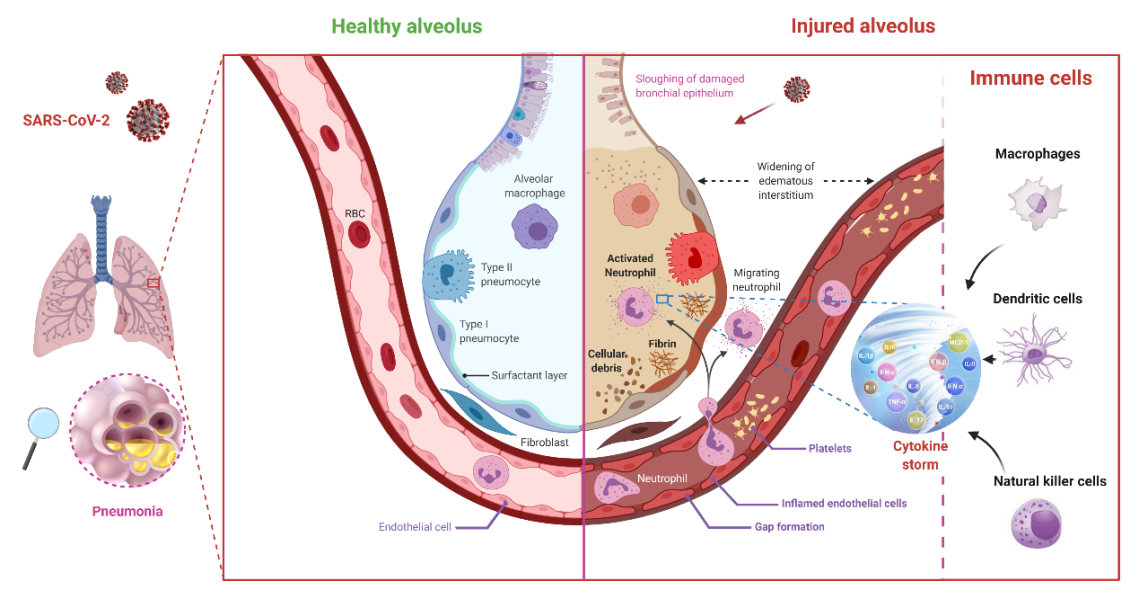

Figure 5. The potential mechanism of SARS-CoV-2 inducing cytokine storm.

1. Treatment strategy of COVID-19

2. Crucial SARS-CoV-2 targets for novel drug development

The preceding overview of the virology of SARS-CoV-2, as well as the sundry potential mechanisms of damage to the host, lay the foundation for developing specific targeted treatment and prevention. A general idea of pivotal targets for drug discovery is shown in Figure 6. In consideration of the role of the surface structural $\mathrm{S}$ in the virus-cell receptor interplay, it is of particular interest for the antiviral development. mAbs against the S1 subunit RBD and fusion inhibitors targeting the S2 subunit possess potential antiSARS-CoV-2 capacityin vitro or in vivo (Yuan et al., 2004). Besides, since ACE2 is the key functional host receptor of SARS-CoV-2 to determine the pathogenicity, mAbs, or molecules targeting the host receptor are effective anti- SARS-CoV-2 drugs, as long as they do not elicit immunopathological effects in animal models (Zumla et al., 2016). A recent study also probed into the COVID-19 S protein-binding site to the cell-surface receptor (known as Glucose Regulated Protein 78 (GRP78)). Their outcomes unveiled that the 
binding between regions III and IV of the S protein model and GRP78 was more favorable. In this regard, region IV is the major tractive force for GRP78 binding, and these 9 residues can be leveraged to design therapeutics specific against this disease (Ibrahim et al., 2020). Of note, although inhibitors of the proteases that prime $\mathrm{S}$ for fusion possess antiviral activity, multiple inhibitors are needed because $\mathrm{S}$ can utilize a variety of proteases for priming (Sun et al., 2020). In addition, agents directly targeting the highly conserved S2 subunit may be potential treatment candidates.

For SARS-CoV-2, the large replicase polyprotein 1a (pp1a) and pp1ab encoded by the ORF1a/b are subjected to two viral proteases, papain-like protease $\left(\mathrm{PL}^{\text {pro }}\right)$ and $3 \mathrm{C}$ cleavage-like protease $\left(3 \mathrm{CL}^{\text {pro }}\right)$ (also known as $\mathrm{M}^{\text {pro }}$ ), for producing non-structural proteins (i.e., RdRp, helicases) which are correlated to viral transcription and replication (Figure 3) (Zumla et al., 2016). Therefore, enzyme inhibitors targeting these proteins may exhibit anti-SARS-CoV-2 activity in vitro . A recent study has uncovered that the $\mathrm{M}^{\text {pro }}$ of SARS-CoV-2, which is the translated polyproteins of ORF $1 \mathrm{a} / \mathrm{b}$, is a crucial enzyme that mediates viral replication and transcription (Dai et al., 2020). Specifically, a Gln residue almost always requires a substrate at P1 (an amino acid in substrates). There is currently no human homologous for $\mathrm{M}^{\text {pro }}$, which makes it a promising antiviral target (Figure 6) (Yang et al., 2005). Dai and coworkers had conducted the structure-based design of antiviral agents targeting this protease by parsing out the substrate-binding pocket of $M^{\text {pro }}$ (Dai et al., 2020). In this regard, further study targeting such a protease may give rise to certain antiviral drug candidates.

Another notable drug target may be the cellular enzymes that attach fatty acids to a cluster of cysteines in the cytoplasmic tail of $\mathrm{S}$ due to the fact that fatty acids are essential for the fusion of host cell and assembly of the virus, like the description of other S proteins, such as hemagglutinin for influenza viruses. The enzyme that connects the acyl chain to $\mathrm{S}$ has not yet been discovered, but the cellular protein will undergo acetylation by the members from the ZDHHC family with unique, only partially overlapping substrate specificities. If a few of them may be acetylated in the airway cells of the lungs, their blockage may suppress the viral replication, and the acylation of cellular proteins will rarely be damaged. In this regard, targeting acyltransferases may be promising, because the cysteine group is existed in all CoV genus $\mathrm{S}$, in spite of their source (Gadalla and Veit, 2020). However, in consideration of the palmitoylation of crucial proteins in the innate immunity, if the proteins of the innate immune response are modified with the same enzymes as viral proteins, the acylation inhibitor may be limited.

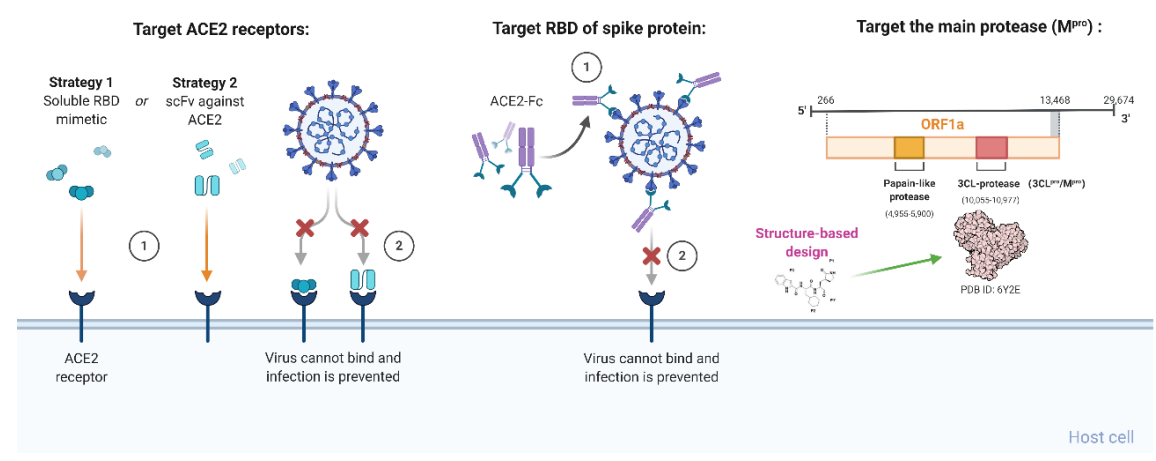

Figure 6. Crucial SARS-CoV-2 targets for novel antiviral drug development.

The last point of view is the application of small interfering RNAs (siRNAs). SARS-CoV-2 can disintegrate in host cells, releasing the nucleocapsid and viral RNA into the cytoplasm, and then translate ORF1a / b into ppla and pplab for genomic RNA replication (van Boheemen et al., 2012). Hence, siRNAs targeting structural genes may play a role in the SARS-CoV-2 infections, and further optimizing the delivery of siRNAsin vivo may make them clinically valuable.

\subsection{Drug discovery approaches toward anti-SARS-CoV-2 drug screening}


The drug discovery strategy bears the brunt of the COVID-19 outbreak is the test of existing broad-spectrum antiviral agents that have been harnessed to cure other viral infections via utilizing standard tests for measuring the effects of drugs on the cytopathy, virus production along with plaque generation in live and pseudotyped CoVs. Drug discovery utilizing this method encompass interferon $\alpha$, interferon $\beta$, interferon $\gamma$, arbidol, ribavirin, along with cyclophilin inhibitors (Cheng et al., 2007; Khamitov et al., 2008). These drugs possess the distinct preponderance of easy access to known pharmacokinetic and pharmacodynamic features, dose regimens, and adverse effects (Cinatl et al., 2003). Nevertheless, they have no specific anti-SARS-CoV-2 effect and may be correlated with severe untoward effects.

In addition to the test of existing broad-spectrum antiviral agents, another anti-SARS-CoV-2 drug discovery approach might be the chemical libraries screening, which involves a good deal of existing compounds or databases with the information on transcriptional signatures in disparate cell lines (Dyall et al., 2014; Kindrachuk et al., 2015). Such a method holds the potential of offering a prompt, high-throughput screening of many off-the-shelf composites, which can thereby be further assessed via antiviral detection test. Importantly, a variety of different types of agents have been discovered among these agent repurposing programs, incorporating many that with significant physiological and immune effects (i.e., those affecting the lipid or sterol metabolism, regulation of neurotransmitters, kinase signaling, estrogen receptors, and DNA synthesis/repair) (Elshabrawy et al., 2014; de Wilde et al., 2014). It is noteworthy that this method has the main drawback that most agents are not clinically useful in virtue of their underlying immunosuppressive effects or anti-SARS-CoV-2 half-maximal effective concentration values that significantly surpass the peak serum concentration levels that are obtainable at the therapeutic dose (Que et al., 2003). An interesting exception is the anti-HIV protease inhibitor lopinavir-ritonavir, which has been reported to be effective for SARS-CoV in both non-human primate models and in non-randomized clinical trials (Chu et al., 2004). In addition, nelfinavir, a selective inhibitor of HIV protease, which has been demonstrated to possess a sound suppresion of SARS-CoV, suggestive of a potential drug candidate for COVID-19 (Yamamoto et al., 2004).

The most critical method for anti-SARS-CoV-2 drug discovery includes the de novo development of new, specific drugs based upon the genomic and biophysical understanding of this virus. For instance, the determination of key SARS-CoV-2 targets may bring about the production of siRNA molecules or inhibitors against specific viral enzymes correlated with viral replication. Additionally, mAb targeting host receptors, inhibitors of host cell proteases, host cell endocytosis viruses, along with humanized mAb targeting the RBD, and antiviral peptides targeting the S2 subunit offer various methodology and options for the design and development of possible therapeutics. With the emerging outbreak of the COVID-19 pandemic, the abovementioned methods are critical for identifying candidate drug composites that can be widely categorized into virus-based and host-based therapy options.

\section{Therapeutics options for SARS-CoV-2 in clinical}

During the outbreak of the pandemic COVID-19, considerable efforts are underway to discover novel therapeutic drugs for $\mathrm{CoV}$ infections. A wide variety of agents has been selected as therapeutic options for SARS-CoV-2 in clinical trials (Table 1).

Table 1. List of candidate therapeutic drugs for SARS-CoV-2 therapy in clinical trials.

\begin{tabular}{|c|c|c|c|c|}
\hline Category & $\begin{array}{l}\text { Candidate } \\
\text { therapeutics }\end{array}$ & Modality & Manufacturer & $\begin{array}{l}\text { Status of } \\
\text { clinical trials }\end{array}$ \\
\hline \multirow[t]{2}{*}{ Nucleoside Analogs } & $\begin{array}{l}\text { Pegylated interferon } \\
\text { with ribavirin } \\
\text { (Al-Tawfiq et al., } \\
2014 \text { ) }\end{array}$ & / & Valeant & $\begin{array}{l}\text { Under clinical trial } \\
\text { for COVID-19 } \\
\text { (ChiCTR2000029387) }\end{array}$ \\
\hline & $\begin{array}{l}\text { Favipiravir } \\
(\mathrm{T}-705)(\mathrm{De} \\
\text { Clercq, 2019) }\end{array}$ & $\begin{array}{l}\text { A guanine analog } \\
\text { for the treatment } \\
\text { of influenza virus } \\
\text { infections }\end{array}$ & Toyama & $\begin{array}{l}\text { Under clinical } \\
\text { trial for } \\
\text { COVID-19 } \\
\text { (ChiCTR2000029548) }\end{array}$ \\
\hline
\end{tabular}




\begin{tabular}{|c|c|c|c|c|}
\hline Category & $\begin{array}{l}\text { Candidate } \\
\text { therapeutics }\end{array}$ & Modality & Manufacturer & $\begin{array}{l}\text { Status of } \\
\text { clinical trials }\end{array}$ \\
\hline & $\begin{array}{l}\text { Remdesivir } \\
\text { (Holshue et al., } \\
\text { 2020) (GS-5734) }\end{array}$ & $\begin{array}{l}\text { An adenine analog } \\
\text { with a similar } \\
\text { chemical structure } \\
\text { to the approved } \\
\text { HIV reverse } \\
\text { transcriptase } \\
\text { inhibitor tenofovir } \\
\text { alafenamide. }\end{array}$ & Gilead & $\begin{array}{l}\text { Phase II clinical } \\
\text { trial for Ebola } \\
\text { (NCT03719586); } \\
\text { Under phase III } \\
\text { clinical trials for } \\
\text { COVID-19 } \\
\text { (NCT04252664) }\end{array}$ \\
\hline Type I interferons & $\begin{array}{l}\text { IFN- } \beta 1 \text { (Sallard } \\
\text { et al., 2020) }\end{array}$ & $\begin{array}{l}\text { Used as a } \\
\text { treatment for } \\
\text { multiple sclerosis }\end{array}$ & $\begin{array}{l}\text { Multiple } \\
\text { companies }\end{array}$ & $\begin{array}{l}\text { Treatment of } \\
\text { COVID-19 in the } \\
\text { early stage }\end{array}$ \\
\hline $\begin{array}{l}\text { Protease } \\
\text { inhibitors }\end{array}$ & $\begin{array}{l}\text { Lopinavir and } \\
\text { ritonavir } \\
\text { (Yamamoto et al., } \\
2004 \text { ) }\end{array}$ & $\begin{array}{l}\text { Protease } \\
\text { inhibitors } \\
\text { approved as } \\
\text { anti-HIV drugs }\end{array}$ & Abbott & $\begin{array}{l}\text { Under clinical } \\
\text { trials for SARS; } \\
\text { Under clinical } \\
\text { trial for } \\
\text { COVID-19 } \\
\text { (ChiCTR2000029539) }\end{array}$ \\
\hline Chloroquine & $\begin{array}{l}\text { Chloroquine and } \\
\text { hydroxychloro- } \\
\text { quine (CDC, } \\
2020)\end{array}$ & $\begin{array}{l}\text { Oral prescription } \\
\text { drugs for } \\
\text { treatment of } \\
\text { malaria and } \\
\text { certain } \\
\text { inflammatory } \\
\text { conditions }\end{array}$ & $\begin{array}{l}\text { Multiple } \\
\text { companies }\end{array}$ & $\begin{array}{l}\text { Under } \\
\text { investigation in } \\
\text { clinical trials for } \\
\text { pre-exposure or } \\
\text { post-exposure } \\
\text { prophylaxis of } \\
\text { SARS-CoV-2 } \\
\text { infection }\end{array}$ \\
\hline Antibodies & $\begin{array}{l}\text { CR3022 (Tian et } \\
\text { al., 2020) }\end{array}$ & $\begin{array}{l}\text { A SARS } \\
\text { Cov-specific } \\
\text { human } \\
\text { monoclonal } \\
\text { antibody }\end{array}$ & $\begin{array}{l}\text { Multiple } \\
\text { companies }\end{array}$ & $\begin{array}{l}\text { Experimental } \\
\text { phase }\end{array}$ \\
\hline
\end{tabular}

\subsubsection{Antiviral agents}

Nucleoside Analogs

Nucleoside analogs can interfere with cellular nucleotide synthesis pathways and terminate viral genome replication through accumulating mutations and cutting off the entry of natural nucleotides (Wang et al., 2016). Since nucleosides and nucleotides are the basic components of viral nucleic acids, nucleoside analogs serve as viral RNA synthesis inhibitors in a wide spectrum of RNA viruses. With the view of the targeting ability toward RdRp, nucleoside analogs are responsible for viral RNA replication (Debing et al., 2014).

Ribavirin is a guanine analog among approved nucleoside analogs used to treat hepatitis c virus and respiratory syncytial virus infections and has been harnessed to cure patients with SARS (So et al., 2003). Ribavirin was extensively leveraged for patients with or without concomitant usage of steroids during the SARS outbreak in 2003 (Wenzel and Edmond, 2003). When combined with IFN- $\beta$, it can exert the synergistical inhibition effect on SARS-associated coronavirus replication in vitro (Morgenstern et al., 2005). However, the efficacy and safety of this agent remain uncertain, and it may arouse adverse reactions like anemia in high doses (Al-Tawfiq et al., 2014). In COVID-19 therapy, ribavirin was utilized with pegylated interferon for stimulating the innate antiviral reaction at a relatively lower dose to curtail side effects. 
In addition, another promising guanine analog is favipiravir (T-705), which has been approved in Japan for the therapy of influenza virus infections and has also been demonstrated to suppress the replication of Ebola, yellow fever, enterovirus, and norovirus (De Clercq, 2019). Recently, Wang and coworkers suggested that favipiravir may also be a potential candidate for COVID-19 therapy, which showed effective antiviral activity in Vero E6 cells with an EC50 value of around $61 \mu \mathrm{M}$. To improve the condition of COVID-19 patients, favipiravir was utilized with other antiviral drugs like baloxavir marboxil (Wang et al., 2020b).

As an adenine analogue with a similar chemical structure to the approved HIV reverse transcriptase inhibitor tenofovir alafenamide, remdesivir (GS-5734) exhibits broad-spectrum antiviral activity against several RNA viruses and has the capacity of competing with RdRp (Tchesnokov et al., 2019). It also possesses outstanding in vitro antiviral activity compared with lopinavir and ritonavir (Sheahan et al., 2020). In the United States, the first case of SARS-CoV-2 infection was reported, and remdesivir was administered. The patient's clinical condition improved after only one day of remdesivir treatment (Holshue et al., 2020). A newly released research offered remdesivir for COVID-19 inpatients on the basis of sympathy. In the cohort of patients admitted for treatment of severe COVID-19, patients treated with sympathetic remdesivir achieved relatively good clinical improvement (36 of 53 patients (68\%)) (Grein et al., 2020). However, recently, leaked data from a crucial remdesivir investigation suggests this potent coronavirus agent may not be effective. Although the chief medical officer of Gilead Sciences said that the summary post online might include inappropriate characterizations of the study and the study was terminated early due to low enrollment (Park, 2020). The real anti-SARS-CoV-2 activity of remdesivir need to be further studied in the near future.

\section{Type I interferons}

Type I interferons designate a cluster of antiviral cytokines consisting of the omnipresent $\alpha$ and $\beta$ subtypes, along with the $\omega, \varepsilon$ and $\chi$ subtypes, inducing large numbers of proteins that can undermine viral replication in host cells (Samuel, 2001). Former researches have revealed that IFN- $\beta$ was superior against SARS-CoV in comparison with IFN- $\alpha$ (Scagnolari et al., 2004). As for the clinical trial of type I interferons, in China, therapy guidelines for COVID-19 recommend the management of 5 million $\mathrm{U}$ of IFN- $\alpha$ via vapor inhalation in patients twice daily with ribavirin as combined therapy (Dong et al., 2020). In the detailed study of Sallard et al., they reported that IFN- $\beta 1$ might constitute a safe and easy to upscale therapy against COVID-19 in the early stages of the disease. Besides, the in vitro data indicated that this virus might be significantly more sensitive to IFN-I than other CoVs (Sallard et al., 2020).

\section{Protease inhibitors}

Protease inhibitors (PIs) are promising candidates for antiviral agents. PIs can block the replication of viral genes via binding to enzymes that are responsible for proteolysis (Wu et al., 2004). Lopinavir and ritonavir, both protease inhibitors, have been approved as HIV medicines and have been found to possess antiviral activity against SARS and MERS. For the sake of destroying the SARS-CoV-2, clinical trials had begun to parse out the antiviral property of HIV protease inhibitors among patients. Notwithstanding, the antiviral effect of such inhibitors in coronavirus proteases remains controversial. Notably, a study regarding the comparison of the efficacy of prophylactic remdesivir and therapeutic remdesivir in combination with lopinavir, ritonavir, and interferon $\beta$ against MERS-CoV unveiled that remdesivir was more effective than the combination therapy in reducing viral load and improving the degree of pathological changes in lung tissue. Aside from the gastrointestinal adverse reactions aroused by lopinavir/ritonavir, it is worth noting that lopinavir/ritonavir treatment alone may fail to offer benefits in comparison with standard care alone. The median time for clinical improvement was 16 days, and the reduction in viral RNA load among patients with severe SARS-CoV-2 did not appear to differ in both cases (B. Cao et al., 2020). Despite the disheartening outcomes, a marginally lower number of deaths were observed among the patients with lopinavir/ritonavir treatment in the late stage of this disease in contrast to the standard-care group. Further, Baden et al. suggested that the concentration of lopinavir/ritonavir required to inhibit the replication of SARS-CoV-2 in the lungs may be higher than the serum level (Baden and Rubin, 2020). Besides, nelfinavir, which is a selective inhibitor of HIV protease, has also been displayed to possess a robust suppression of SARS-CoV, indicating an alternative therapeutic option for COVID-19 (Yamamoto et al., 2004). 


\subsubsection{Chloroquine, hydroxychloroquine and azithromycin}

Chloroquine, as a drug extensively utilized in anti-malaria and autoimmune diseases, has been found to be a potential broad-spectrum antiviral agent (Savarino et al., 2006). It can prevent viral infections via elevating the endosomal $\mathrm{pH}$ needed for virus-cell fusion and disturbing the glycosylation of SARS-CoV cell receptors (Figure 7) (Vincent et al., 2005). Gao et al. revealed that chloroquine phosphate was effective in the therapy of COVID-19-associated pneumonia (Gao et al., 2020). Wang and coworkers also conducted in vitro study, and they found that it is an ideal candidate antiviral drug against SARS-CoV-2 infection in Vero E6 cells with EC50 value of around one $\mu \mathrm{M}$ (Wang et al., 2020b). Although several trials had verified that chloroquine suppresses the exacerbation of COVID-19, the optimal dosage of chloroquine will require to be evaluated in future trials (Gao et al., 2020).

Hydroxychloroquine is an analog of chloroquine, and there are few studies on its interaction (Jallouli et al., 2015). In previous SARS outbreaks, hydroxychloroquine was found to possess anti-SARS-CoV capacity in vitro (Figure 7) (Biot et al., 2006). In line with the research of Yao et al., by applying a physiologically based pharmacokinetic model, they found that hydroxychloroquine is more effective than chloroquine in Vero cells infected with SARS-CoV-2 (Yao et al., 2020). Of note, it has been revealed that cytokines IL-6 and IL-10 are elevated in response to SARS-CoV-2 infection, which may induce the cytokine storm (Figure 5), which in turn cause multiple organ failure and death (Huang et al., 2020). Both chloroquine and hydroxychloroquine possess immunomodulatory effects and can inhibit such immune responses (Schrezenmeier and Dörner, 2020).

Hence, Chinese hospitals and Oxford University had initiated 21 clinical studies to evaluate the efficacy of these drugs in COVID-19 infection. The further crucial study may relate with the determination of whether the benefit of chloroquine treatment is hinged on the age of the patients as well as the clinical manifestations (Touret and de Lamballerie, 2020).

According to reports, azithromycin is can suppress Zika virus and Ebola virus in vitro and can be harnessed to restrain severe respiratory infections in infected patients. Gautret and colleagues found that azithromycin can significantly reinforce the efficacy of hydroxychloroquine after treating 20 patients with severe COVID-19 (Gautret et al., 2020). In this regard, the regimen of hydroxychloroquine, in combination with azithromycin may be a potential alternative to remdesivir in the therapy of COVID-19 diseases in the future. 


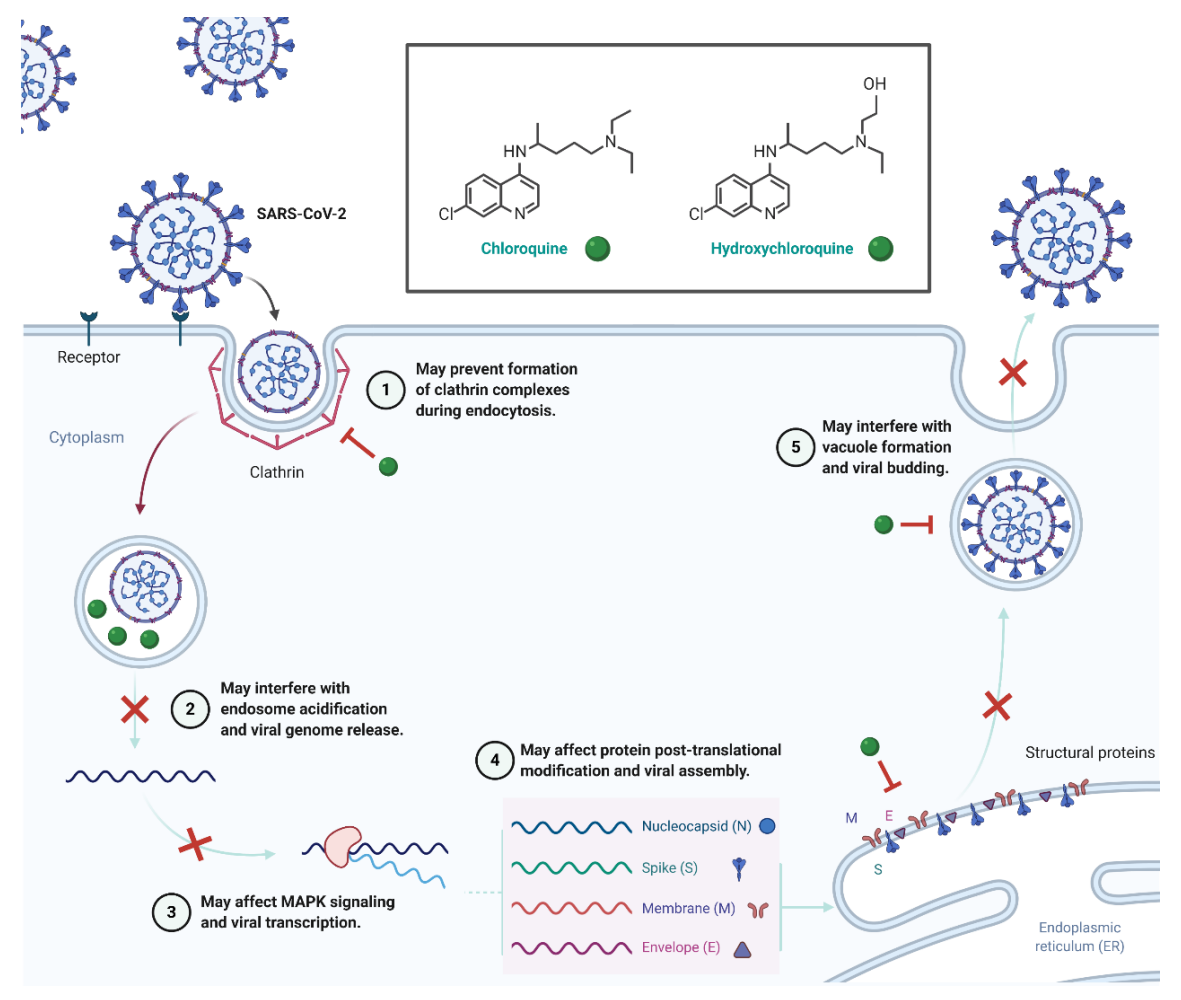

Figure 7. Potential antiviral mechanism of chloroquine and hydroxychloroquine against SARSCoV-2.

\subsubsection{Monoclonal or polyclonal antibodies}

Monoclonal or polyclonal antibodies have been recommended as tools for preventing and treating viral infections. Considering the relatively high RBD in SARS-CoV-2, the cross-reactivity of anti-SARS-CoV antibodies with the COVID-19 S protein was evaluated. Tian et al. determined the potent binding of $\mathrm{S}$ protein via a SARS coronavirus-specific human mAb CR3022 (Tian et al., 2020). Unfortunately, other SARS-CoV RBD directed mAbs (i.e., 230, m396, and 80R) cannot bind to the COVID-19 RBD (Wrapp et al., 2020). In this respect, CR3022 may be a promising therapeutic candidate, either alone or in combination with other neutralizing mAbs, for the therapy of COVID-19 disease. In addition, tocilizumab is a monoclonal antibody for the therapy of RA exacerbation. It was designed to suppress the binding of IL-6 to its receptors, hence mitigating cytokine release syndrome. At present, it is also being trailed for the COVID-19 therapy (Jean et al., 2020).

Besides, most patients with severe COVID-19 suffered a lot from the cytokine storm (Figure 5) (Xu et al., 2020). So, neutralizing antibodies against other pro-inflammatory cytokines may be another promising strategy to dampen the inflammatory responses, thus responding well to treat the COVID-19. In a clinical trial conducted in Anhui, China, IL-6 receptor-targeted mAb tocilizumab was utilized to treat 21 patients with severe COVID-19. Clinical data showed quick fever control and improved respiratory function (Cao, 2020). Overall, the development of COVID-19-specific antibodies takes a long time, meaning the difficulty in applying antibodies for neoteric pathogens to clinical practice in a brief period.

\subsubsection{Corticosteroids}

As a class of drug that lowers inflammation in the body, corticosteroids have been utilized in several serious viral respiratory infections such as SARS-CoV and MERS-CoV with limited benefits. However, in some cases, there is proof of delayed viral clearance and increased rates of secondary infection and mortality (Russell et 
al., 2020). In a study of 41 COVID-19 patients, $22 \%$ were given corticosteroids, which inhibit inflammation in the lungs (Huang et al., 2020). However, according to the current WHO interim guidance, glucocorticoids are not recommended for routine treatment unless otherwise indicated, as other coronaviruses and influenza studies have identified possible injury and increased risk of death from glucocorticoid therapy (Zhou et al., 2020a). Despite the potential antiviral activity toward COVID-19, corticosteroids should not be given principally, and corticosteroid pulse therapy should be conducted with caution. In addition, corticosteroid therapy for the SARS therapy yielded adverse effects such as psychosis, diabetes, and avascular necrosis (Lee et al., 2004). In general, the treatment with corticosteroids may be harmful, but such agents can be prescribed to the right patient at the proper time.

\subsubsection{Convalescent plasma transfusion}

Convalescent plasma has also been utilized as a last resort to improve the survival in patients with miscellaneous viral infections (i.e., SARS, H5N1, H1N1, and Ebola virus infection) (Chen et al., 2020b). The theoretical basis for the therapeutic effect of plasma in the recovery phase is that immunoglobulin Abs in the plasma of patients recovering from the viral infection may inhibit viremia. To date, in the previous SARS therapy, convalescent plasma given early after the onset of symptoms reduced overall mortality after treatment compared to placebo or no treatment (Mair-Jenkins et al., 2015). For the test of convalescent plasma effect on COVID-19 infection, Zhou et al. found that the SARS-CoV-2 isolated from bronchoalveolar lavage fluid in a severe patient could be neutralized by the serum of several patients (Zhou et al., 2020b). Additionally, another study of Shen et al. showed that improvements in clinical conditions were observed following plasma transfusions, improvements included normalization of body temperature within three days, a decrease in Sequential Organ Failure Assessment score, resolution of ARDS, and decline in viral loads (Shen et al., 2020). During the emerging of COVID-19 infection in China, the National Health Commission of China also called on convalescent patients to donate blood for COVID - 19 therapy. Despite the difficulty in collecting the plasma, convalescent plasma therapy showed great therapeutic potential for the COVID-19 therapy.

\subsubsection{Herbal medications}

Based on data mining, the Traditional Chinese Medicine was also regarded as an alternative method for the treatment of COVID-19 disease in high-risk populations. During the COVID-19 outbreak in China, Chinese herbal drugs such as Astragali Radix, Glycyrrhizae Radix Et Rhizoma, Atractylodis Macrocephalae Rhizoma, Saposhnikoviae Radix, Lonicerae Japonicae Flos and Fructus forsythia were commonly harnessed for improving the treatment effect of COVID-19 infections. Herbal medications can offer a more effective and personalized treatment by adjusting the specific medicine for each patient based on the disparate syndromes (DU et al., 2020). Previous studies also indicated that the patients with SARS-CoV infection have benefited from TCM treatment (Liu et al., 2012), involving amelioration of adverse effects of tranditional therapeutics. Some TCM such as Lianhuaqingwen capsules exert anti-viral replication and anti-inflammatory activity against SARS-CoV-2 in vitro (Runfeng et al., 2020). However, the experimental study on the efficacy of herbal medicines lags behind the clinical application of traditional Chinese medicine in the COVID-19 treatment (Yang et al., 2020b). Hence, rigorous clinical trials on large populations should be carried out to identify the potential therapeutic efficacy of herbal medications.

\subsubsection{Mesenchymal stem cell therapy}

Stem cell therapy is also making its way into COVID-19 disease treatment. Recently, some researches have demonstrated that the intravenous transplantation of mesenchymal stem cells (MSCs) was safe and efficient for COVID-19 pneumonia, especially for critically ill patients (Leng et al., 2020). As mentioned, COVID-19 infection may induce uncontrolled inflammatory innate reactions along with undermined adaptive immune reactions, subsequently leading to detrimental tissue damage. MSC-based immunomodulation treatment is able to counteract the cytokine storm aroused by the immune system and foster endogenous repair via reparative attributes of the stem cells (Golchin et al., 2020). As it is unveiled by the recent study of China, seven COVID-19 patients ( 1 critically ill patient, 4 critically ill patients, and 2 patients with mild symptoms) 
received intravenous injection of bone marrow MSCs. In all cases, the patients were cured, while the 3 patients in the placebo control group all suffered from severe illness, 1 died, 1 developed ARDS, and 1 was in stable condition (Williams, 2020). This study uncovered that MSCs could reclaim the lung microenvironment, protect the alveolar epithelial cells, block pulmonary fibrosis, and treat pulmonary dysfunction (Leng et al., 2020). Notably, the FDA has also opened the way to the compassionate use of MSCs intravenous infusions in patients with COVID-19 ARDS and very dismal prognosis (Bioscience Institute, 2020). Although such a kind of treatment is an ideal option for COVID-19 therapy, it has limitations regarding the supply of clinical-grade MSCs and the rate of preparation for subsequent clinical use.

\subsubsection{Other therapies}

Hydrogen peroxide $\left(\mathrm{H}_{2} \mathrm{O}_{2}\right)$ appears to be another potential therapeutic option for COVID-19. Of note, health experts have said that this compound could help prevent the virus from spreading across the body and from causing damage (Darwin Malicdem, 2020). A recent study illustrated that even just $0.5 \%$ of hydrogen peroxide could kill human coronaviruses, such as those that caused SARS and MERS (Kampf et al., 2020). Inhaling the vapor with a nebulizer has been the most convenient way to receive $\mathrm{H}_{2} \mathrm{O}_{2}$ to fight viral infections. The microscopic mist can easily penetrate the nostrils, sinuses, and lungs, which are commonly affected by respiratory diseases like COVID-19. Besides, molecular hydrogen has been verified to favorably modulate the generation of both $\mathrm{O}_{2}{ }^{-}$and NO through influencing NADPH oxidase, and the NOS enzymes (TW, LeBaron, McCullough ML, 2020). According to the National Health Commission of China, the conditional use of mixed inhalation of hydrogen and oxygen $\left(\mathrm{H}_{2} / \mathrm{O}_{2}: 66.6 \% / 33.3 \%\right)$ treatment may improve the symptoms (Sohu, 2020).

Lung transplantation can be performed in advanced patients with respiratory failure owing to COVID-19related pulmonary fibrosis. As it is reported in a clinical study, lung transplantation may offer the ultimate treatment option for severe patients to avoid certain deaths, while at the same time protecting transplantation doctors and medical staff appropriately (Chen et al., 2020a).

\section{Development of SARS-CoV-2 vaccines}

In terms of controlling the epidemic aroused by emerging viruses, rapid diagnosis and effective vaccines serve as a complementation to antiviral therapy. Preventive and therapeutic SARS-CoV-2 vaccines will be of fundamental value as the most conspicuous way to mitigate the pandemic crisis (André, 2001). Fortunately, published data on the SARS-CoV-2 genetic sequence has sparked a global campaign to inaugurate a vaccine against the infections. The scope of the impact of the COVID-19 pandemic on humanitarianism and the economy is also prompting the assessment of the next-generation vaccine technology platform through new paradigms. On March 16, 2020, the first trial of COVID-19 vaccine candidate was launched in record speed. Moreover, the Coalition for Epidemic Preparedness Innovations (CEPI) is also combining efforts to espouse the development of vaccines against COVID-19.

As for the vaccine development of SARS-CoV-2, the pivotal and tangible avenues can be divided into four aspects: 1) Selection of antigen epitope. 2) Overcoming the antibody-dependent enhancement (ADE) issue. 3) Weighing humoral immunity and cellular immunity. 4) Selection of technical route befittingly. Up till now, structural epitope mapping by homology modeling has uncovered the immunoreactive antigen epitopes of SARS-CoV-2 (Tilocca et al., 2020). The mainstream of the vaccine development is based upon the S protein in virtue of its essential role in the viral infectivity. Other subsequent developments can constrain focus on other viral proteins (i.e., the $\mathrm{N}$ protein, and E protein). Further, the titers of neutralizing antibodies that were variable among different patients were associated with the spike-binding Abs targeting S1, RBD, and $\mathrm{S} 2$ regions (Wu et al., 2020a). In this regard, we should also pay more attention to the titers of neutralizing antibodies.

In addition, researchers need to know whether the vaccine will induce the same type of immune system failures that have been observed previously. In some cases, the vaccine-primed immune system seems to initiate a shoddy response to natural infections (Peeples, 2020). Additionally, allergic inflammation aroused by Th2 immunopathology should be taken into consideration, according to the coronavirus experts (Peeples, 
2020). Therefore, animal and human clinical trials of COVID-19 candidate vaccines should encompass a rigorous assessment of possible immune complications before putting into use.

According to the previous study on SARS-CoV, SARS-specific IgG Ab may ultimately fade away, and the peripheral memory B cell response cannot be detected in recovered SARS patients. In stark contrast, the memory response of specific $\mathrm{T}$ cells lasted at least six years, implicating the significance of cellular immunity for preventing the recurrence epidemics (Tang et al., 2011).

With regard to the technical routes, we can see efforts to espouse 'quick-fix' programs for the purpose of developing vaccines against COVID-19 worldwide (Jiang, 2020). There is a desperate need for selecting effective technical routes to develop different kinds of vaccines (i.e., live-attenuated vaccines, inactivated vaccines, nucleic acid vaccines, subunit, recombinant, polysaccharide, and conjugate vaccines) in a quicker and safer manner (HHS.gov, 2020).

As announced by the WHO, there are now more than 70 potential vaccines under development, with three already in clinical trials (Keown, 2020). The following section will describe the status of vaccine development against this crisis by miscellaneous methods. The potential vaccine candidates for COVID-19 are summarized in Table 2 .

Table 2. The potential vaccine candidates for COVID-19 (Le et al., 2020; Hodgson, 2020; Times, 2020; ARENA, 2020; ChiCTR, 2020).

\begin{tabular}{|c|c|c|c|c|}
\hline Phase & Candidate & $\begin{array}{l}\text { Vaccine } \\
\text { characteristics }\end{array}$ & $\begin{array}{l}\text { Lead devel- } \\
\text { oper/sponsor }\end{array}$ & Current status \\
\hline \multirow[t]{4}{*}{ Clinical-phase } & INO-4800 & $\begin{array}{l}\text { DNA plasmid } \\
\text { encoding S } \\
\text { protein delivered } \\
\text { via } \\
\text { electroporation }\end{array}$ & $\begin{array}{l}\text { Inovio } \\
\text { Pharmaceuticals }\end{array}$ & $\begin{array}{l}\text { Phase I } \\
\text { (NCT04336410) }\end{array}$ \\
\hline & mRNA-1273 & $\begin{array}{l}\text { LNP- } \\
\text { encapsulated } \\
\text { mRNA vaccine } \\
\text { encoding S } \\
\text { protein }\end{array}$ & Moderna & $\begin{array}{l}\text { Phase I } \\
\text { (NCT04283461) }\end{array}$ \\
\hline & LV-SMENP-DC & $\begin{array}{l}\text { DCs modified } \\
\text { with lentiviral } \\
\text { vector expressing } \\
\text { synthetic } \\
\text { minigene based } \\
\text { upon domains of } \\
\text { selected viral } \\
\text { proteins; }\end{array}$ & $\begin{array}{l}\text { Shenzhen } \\
\text { Geno-Immune } \\
\text { Medical Institute }\end{array}$ & $\begin{array}{l}\text { Phase I } \\
\text { (NCT04276896) }\end{array}$ \\
\hline & / & $\begin{array}{l}\text { Recombinant } \\
\text { novel coronavirus } \\
(2019-\mathrm{CoV}) \\
\text { vaccine } \\
\text { (adenoviral } \\
\text { vector) }\end{array}$ & $\begin{array}{l}\text { Institute of } \\
\text { Military Medicine } \\
\text { under the } \\
\text { Academy of } \\
\text { Military Sciences } \\
\text { of the People's } \\
\text { Liberation Army } \\
\text { of China }\end{array}$ & $\begin{array}{l}\text { Phase II } \\
\text { (ChiCTR2000030906) }\end{array}$ \\
\hline
\end{tabular}




\begin{tabular}{|c|c|c|c|c|}
\hline Phase & Candidate & $\begin{array}{l}\text { Vaccine } \\
\text { characteristics }\end{array}$ & $\begin{array}{l}\text { Lead devel- } \\
\text { oper/sponsor }\end{array}$ & Current status \\
\hline & / & Inactivated vaccine & $\begin{array}{l}\text { Beijing Institute of } \\
\text { Biological } \\
\text { Products/Wuhan } \\
\text { Institute of } \\
\text { Biological Products }\end{array}$ & $\begin{array}{l}\text { Phase I } \\
\text { (ChiCTR2000031809) }\end{array}$ \\
\hline & ChAdOx1 & $\begin{array}{l}\text { Attenuated } \\
\text { adenovirus capable } \\
\text { of producing the } \mathrm{S} \\
\text { protein of } \\
\text { SARS-CoV-2 }\end{array}$ & $\begin{array}{l}\text { University of } \\
\text { Oxford }\end{array}$ & $\begin{array}{l}\text { Phase I/II } \\
\text { (NCT04324606) }\end{array}$ \\
\hline & $\mathrm{Ad} 5-\mathrm{nCoV}$ & $\begin{array}{l}\text { Adenovirus type } 5 \\
\text { vector that } \\
\text { expresses } \mathrm{S} \\
\text { protein }\end{array}$ & $\begin{array}{l}\text { CanSino } \\
\text { Biologicals }\end{array}$ & $\begin{array}{l}\text { Phase I } \\
\text { (NCT04313127) }\end{array}$ \\
\hline & $\begin{array}{l}\text { Pathogen-specific } \\
\text { aAPC }\end{array}$ & $\begin{array}{l}\text { aAPCs modified } \\
\text { with lentiviral } \\
\text { vector expressing } \\
\text { synthetic } \\
\text { minigene based } \\
\text { upon domains of } \\
\text { selected viral } \\
\text { proteins }\end{array}$ & $\begin{array}{l}\text { Shenzhen } \\
\text { Geno-Immune } \\
\text { Medical Institute }\end{array}$ & $\begin{array}{l}\text { Phase I } \\
\text { (NCT04299724) }\end{array}$ \\
\hline \multirow[t]{3}{*}{$\begin{array}{l}\text { Experimental- } \\
\text { phase }\end{array}$} & / & $\begin{array}{l}\text { Single-dose } \\
\text { intranasal } \\
\text { replication- } \\
\text { defective } \\
\text { adenovirus vector } \\
\text { vaccine } \\
\text { incorporating the } \\
\text { SARS-CoV-2 S } \\
\text { protein }\end{array}$ & Altimmune & $\begin{array}{l}\text { Phase } 1 \text { trial } \\
\text { planned for } \\
\text { mid-August. }\end{array}$ \\
\hline & BNT162 & $\begin{array}{l}\text { mRNA vaccine } \\
\text { expressing } \\
\text { codon-optimized } \\
\text { undisclosed } \\
\text { SARS-CoV-2 } \\
\text { proteins }\end{array}$ & BioNTech & $\begin{array}{l}\text { Clinical testing to } \\
\text { begin late April }\end{array}$ \\
\hline & STARR & $\begin{array}{l}\text { Self-transcribing } \\
\text { and replicating } \\
\text { RNA vaccine } \\
\text { expressing } \\
\text { undisclosed } \\
\text { epitopes }\end{array}$ & Arcturus & $\begin{array}{l}\text { Manufacturing } \\
\text { stage }\end{array}$ \\
\hline
\end{tabular}




\begin{tabular}{|c|c|c|c|c|}
\hline Phase & Candidate & $\begin{array}{l}\text { Vaccine } \\
\text { characteristics }\end{array}$ & $\begin{array}{l}\text { Lead devel- } \\
\text { oper/sponsor }\end{array}$ & Current status \\
\hline & / & $\begin{array}{l}\text { Protamine- } \\
\text { complexed } \\
\text { mRNA-based } \\
\text { vaccine expressing } \\
\text { undisclosed } \\
\text { SARS-CoV-2 } \\
\text { protein(s) }\end{array}$ & CureVac & $\begin{array}{l}\text { Phase } 1 \text { planned } \\
\text { in June or July }\end{array}$ \\
\hline & / & $\begin{array}{l}\text { Undisclosed } \\
\text { SARS-CoV-2- } \\
\text { derived synthetic } \\
\text { peptide } \\
\text { conjugated to the } \\
\text { key moiety of the } \\
\text { MHC } \\
\text { II-associated } \\
\text { invariant chain }\end{array}$ & $\begin{array}{l}\text { Generex } \\
\text { Biotechnology }\end{array}$ & $\begin{array}{l}\text { Human trials } \\
\text { planned in June }\end{array}$ \\
\hline & / & $\begin{array}{l}\text { Modified vaccinia } \\
\text { Ankara VLP } \\
\text { vaccine based } \\
\text { upon Wuhan } \\
\text { strain of } \\
\text { SARS-CoV-2 }\end{array}$ & GeoVax & $\begin{array}{l}\text { Candidates in } \\
\text { animal studies }\end{array}$ \\
\hline & / & $\begin{array}{l}\text { Electroporated } \\
\text { linear DNA } \\
\text { vaccine based on } \\
\text { S protein and } \\
\text { selected epitopes }\end{array}$ & LineaRx & $\begin{array}{l}\text { Four candidates } \\
\text { for testing by the } \\
\text { beginning of May } \\
\text { or June }\end{array}$ \\
\hline & / & $\begin{array}{l}\text { Undisclosed } \\
\text { recombinant } \\
\text { SARS-CoV-2 } \\
\text { protein VLP } \\
\text { produced in } \\
\text { tobacco }\end{array}$ & Medicago & $\begin{array}{l}\text { preclinical testing } \\
\text { ongoing with } \\
\text { clinical trials to } \\
\text { begin summer } \\
2020\end{array}$ \\
\hline & / & $\begin{array}{l}\text { Recombinant } \\
\text { subunit vaccine of } \\
\text { SARS-CoV-2 S } \\
\text { protein locked in } \\
\text { prefusion } \\
\text { conformation by } \\
\text { polypeptide } \\
\text { moiety (molecular } \\
\text { clamp) }\end{array}$ & $\begin{array}{l}\text { University of } \\
\text { Queensland }\end{array}$ & $\begin{array}{l}\text { Preclinical as of } \\
\text { mid-March }\end{array}$ \\
\hline
\end{tabular}




\begin{tabular}{|c|c|c|c|c|}
\hline Phase & Candidate & $\begin{array}{l}\text { Vaccine } \\
\text { characteristics }\end{array}$ & $\begin{array}{l}\text { Lead devel- } \\
\text { oper/sponsor }\end{array}$ & Current status \\
\hline & / & $\begin{array}{l}\text { Oral recombinant } \\
\text { adenovirus } 5 \\
\text { vector vaccine of } \\
\text { undisclosed } \\
\text { SARS-CoV-2 } \\
\text { proteins for } \\
\text { mucosal immune } \\
\text { response }\end{array}$ & Vaxart & $\begin{array}{l}\text { Preclinical as of } \\
\text { mid-March }\end{array}$ \\
\hline
\end{tabular}

aAPC, artificial antigen-presenting cell; MHC, major histocompatibility complex class; VLP, virus-like particle; DC, dendritic cell.

\subsection{DNA-based Vaccines}

DNA vaccines provide a precise and flexible tactic to deliver antigens to the immune system and can contain additional sequences of coding molecules to manipulate the results (Rice et al., 2008). So far, a variety of DNA vaccine platforms have been exploited to enhance the vaccine efficacy through electroporation to deliver plasmids and addition of adjuvants, yielding improved the immune responses (Sardesai and Weiner, 2011). Inovio pharmaceuticals have begun pre-clinical trials of a DNA vaccine (named as INO-4800) against COVID-19 (INOVIO, 2020). This vaccine can induce T cell activation via transferring DNA plasmids that express the SARS-CoV-2 S proteins (INOVIO, 2020). This vaccine platform holds the preponderance of producing therapeutic antibodies and activating immune cells to deliver the vaccine to patients through the skin. With the support of CEPI, the corporation is making provision for the first phase of trials in the United States and China (INOVIO, 2020).

\section{2 mRNA-based Vaccines}

The mRNA vaccine is a hopeful alternative to traditional vaccine methods in virtue of its high efficiency, rapid development capabilities, and the potential for low-cost manufacturing (Pardi et al., 2018). Recently, Moderna, Inc. has launched phase I clinical trials for mRNA-1273, which encodes S protein of SARS-CoV-2. This mRNA-vaccine was fabricated with the cooperation of the National Institute of Allergy and Infectious Diseases (MOERNA, 2020). mRNA-1273, which encodes a prefusion-stabilized form of the SARS-CoV-2 spike, is under test for a broad dosing range (25- 250 micrograms) during its phase 1 submission (Hodgson, 2020). The firm further announced that although commercial vaccines are unlikely to be marketed in at least 12 to 18 months, in an emergency, possibly in the fall of 2020, some people, including medical professionals, may obtain the vaccine (MOERNA, 2020).

\subsection{Recombinant Subunit Vaccines}

Subunit vaccines are superior to other types of vaccines since they are highly safe and possess fewer adverse effects via eliciting the immune system without drawing into any infectious viruses (Graham et al., 2013). It has also been reported that the enhancement of $\mathrm{T}$ cell responses and generation of high titer neutralizing Abs were observedin vivo during the vaccine development researches (Okba et al., 2017). Clover Biopharmaceuticals was pre-clinically testing a recombinant subunit vaccine in the light of the S-Trimer of the SARS-CoV-2 (Clover Biopharmaceuticals, 2020). The researchers detected the antigen-specific neutralizing Abs in the sera of fully recovered patients (Clover Biopharmaceuticals, 2020). Besides, GlaxoSmithKline (GSK) disclosed a vaccine which can elicit a protective immune response against SARS. The vaccine contains an S protein immunogen, which was combined with the emulsion adjuvant, GSK2, yielding elevated level of anti-SARS-CoV IgG2a/IgG2b Ab responses. Recently, GSK and Clover Biopharmaceuticals announced a partnership to enhance immune response via introducing GSK's adjuvant system to S-Trimer (GSK, 2020). 
In addition, the team of the University of Queensland is also designing subunit vaccines via the transformative technology, known as "molecular clamp" (University of Queensland, 2020). Molecular clamps are peptides that stabilize surface proteins, improve the recognition of the correct antigens, and lead to a more robust immune response. This vaccine platform can be easily applied to a variety of enveloped viruses and can rapidly manufacture their products (University of Queensland, 2020).

Further, patent application US20060002947 disclosed the fabrication of hybrid peptides comprised of three elements: (a) an invariant chain (Ii) essential peptide; (b) a chemical structure linking the Ii to the antigenic epitope; (c) an antigen epitope binding MHC II molecule. This theory was harnessed to produce Ii-Key/MHC II SARS hybrids. In this respect, Generex reported that they will employ its Ii-Key immune system activation biotechnology to generate a COVID-19 viral peptide vaccine for human clinical practice (Generex, 2020).

\subsection{Other Vaccine Approaches}

Aside from the aforementioned approaches, Genexine Inc. is exploring a new vaccine via utilizing the Hyleukin-7 platform technology (Genexine, 2020). Such a platform may improve the immune responses fusing IL-7 with hyFc, aiming to hybridize IgD and IgG4 for the long-term effect of Fc fusion proteins. Specifically, IgD possesses a flexible hinge structure and can maximize the biological activity (Genexine, 2020; Seo et al., 2014). IgG4 possesses an unexposed junction site that mitigates immunogenicity via preventing antibody-dependent cellular cytotoxicity (Løset et al., 2004; J.-H. Lee et al., 2013). This corporation reported enhanced vaccine efficacy, lung $\mathrm{T}$ cell accumulation, and plasmacytoid dendritic cell growth after Fc-fused IL-7 treatment in the virus infection models (Kang et al., 2017).

\section{Conclusions and inspirations}

Despite prodigious global efforts made to contain SARS-CoV-2, the current COVID-19 epidemic has expanded into a full-blown pandemic, yielding outright panic and economic slowdown. Health-care systems in many regions are overburdened and under-resourced, impelling medical workers and governors to make formerly unthinkable judgments concerning the allotment of medical care. In the wake of such a severe situation, a number of researches have trailed strategies to tackling the direct impact of COVID-19, either by modeling studies of the viral activity or via parsing out potential therapeutic options and finding a vaccine to end the coronavirus pandemic. Although the development of therapeutics and vaccines for the COVID-19 therapy is still in its middle stage, some marked advances have been made from complete genome sequencing of SARS-CoV-2 to the clinical practice of COVID-19 vaccines.

Rapid genome-wide association of SARS-CoV-2, along with international sharing of information, enabled us to generate rapider and more proper diagnostic tools. As set forth, the major fashioned diagnostic tools are qRT-PCR-based approaches, requiring a long time for specimen preparation and analysis, thus putting off the imperative actions for COVID-19 infections. Of note,

In acute respiratory infections, RT-PCR is commonly utilized for detecting pathogenic viruses in respiratory secretions. The positive rate of PCR from oropharyngeal swabs is not very high, implicating the requirement of more swab testing are need to confirm the diagnosis. With the continuous spread of SARS-CoV-2, there is a desperate demand to develop rapid diagnostic methods that can be tested more efficiently.

According to reports, certain drugs are known to effectively treat patients with COVID-19. Nevertheless, the lack of clinical data may render the clinical prognosis difficult to predict. In addition to the judicious design of novel therapeutics that target viral replication or immunopathology, currently, rapid screening of therapeutic agents to repurpose FDA-approved and well-characterized agents might be a more workable method. Considering the severity of the recent zoonotic coronavirus outbreaks, therapeutic drugs for pancoronavirus should be carried out to cope with future outbreaks.

With respect to the detailed exploitation of COVID-19 vaccines, several pharmaceutical corporations and institutions have also launched the project for vaccine development. Notwithstanding, the commercial market for vaccines, especially vaccines for emerging infectious diseases, is confined by the high cost and time required for vaccine development along with the uncertainty of profitability. Accordingly, CEPI is combining efforts 
to encourage the progress of vaccines against COVID-19. Besides, in the near future, the production of a lot of vaccines may bring about the challenge in scaling up manufacturing quickly, because the infrastructure needed will differ in virtue of the vaccine type. Another concern regarding the vaccine development may be the antibody-dependent enhancement issue.

In addition, this global epidemic crisis indicated that host-species expansion or interspecies transmission of neoteric coronavirus to humans might be unavoidable. Clinicians and researchers should combine efforts to swiftly evolve our perception of all facets of SARS-CoV-2 infections and fill in the gaps concerning the emergence of this virus. Ultimately, we can also learn from this epidemic that we need to improve our disease monitoring and surveillance system to prevent such a serious disease outbreak. Digital technologies such as big-data analytics, artificial intelligence, and blockchain technology may also need to be fully exploited and developed, thereby enabling real-time data collection at scale and modeling risk associations immediately to contain the pathophoresis.

Overall, the challenges posed by twenty-first century epidemics are real and changing: future epidemics will be fueled by various internal and external causes. In our response, we must view pandemics as interconnected cycles, not isolated events, and while we cannot forecast specific outbreaks, we can make provision for them.

\section{Declaration of interest}

The authors assert that there is no conflict of interests concerning the publication of this review.

\section{References}

Ahn, D.G., Shin, H.J., Kim, M.H., Lee, S., Kim, H.S., Myoung, J., et al. (2020). Current Status of Epidemiology, Diagnosis, Therapeutics, and Vaccines for Novel Coronavirus Disease 2019 (COVID-19). J. Microbiol. Biotechnol. $30: 313$.

Al-Tawfiq, J.A., Momattin, H., Dib, J., and Memish, Z.A. (2014). Ribavirin and interferon therapy in patients infected with the Middle East respiratory syndrome coronavirus: an observational study. Int. J. Infect. Dis. $20: 42-46$.

Andersen, K.G., Rambaut, A., Lipkin, W.I., Holmes, E.C., and Garry, R.F. (2020). The proximal origin of SARS-CoV-2. Nat. Med. 1-3.

André, F.E. (2001). The future of vaccines, immunisation concepts and practice. Vaccine 19 : $2206-2209$.

ARENA (2020). UK researchers to trial Covid-19 vaccine and plasma therapy.

Backer, J.A., Klinkenberg, D., and Wallinga, J. (2020). Incubation period of 2019 novel coronavirus (2019$\mathrm{nCoV}$ ) infections among travellers from Wuhan, China, 20-28 January 2020. Eurosurveillance 25 :.

Baden, L.R., and Rubin, E.J. (2020). Covid-19-The Search for Effective Therapy.

Bai, Y., Yao, L., Wei, T., Tian, F., Jin, D.-Y., Chen, L., et al. (2020). Presumed asymptomatic carrier transmission of COVID-19. Jama.

Berry, J.D., Jones, S., Drebot, M.A., Andonov, A., Sabara, M., Yuan, X.Y., et al. (2004). Development and characterisation of neutralising monoclonal antibody to the SARS-coronavirus. J. Virol. Methods120 : $87-96$.

Bhadra, S., Jiang, Y.S., Kumar, M.R., Johnson, R.F., Hensley, L.E., and Ellington, A.D. (2015). Real-time sequence-validated loop-mediated isothermal amplification assays for detection of Middle East respiratory syndrome coronavirus (MERS-CoV). PLoS One 10 :.

Bioscience Institute (2020). Stem Cell Therapy: A Promising Treatment for COVID-19?

Biot, C., Daher, W., Chavain, N., Fandeur, T., Khalife, J., Dive, D., et al. (2006). Design and synthesis of hydroxyferroquine derivatives with antimalarial and antiviral activities. J. Med. Chem. 49 : $2845-2849$. 
Boheemen, S. van, Graaf, M. de, Lauber, C., Bestebroer, T.M., Raj, V.S., Zaki, A.M., et al. (2012). Genomic characterization of a newly discovered coronavirus associated with acute respiratory distress syndrome in humans. MBio 3 : e00473-12.

Broughton, J.P., Deng, W., Fasching, C.L., Singh, J., Chiu, C.Y., and Chen, J.S. A protocol for rapid detection of the 2019 novel coronavirus SARS-CoV-2 using CRISPR diagnostics: SARS-CoV-2 DETECTR.

Cao, B., Wang, Y., and Wen, D. A trial of lopinavir-ritonavir in adults hospitalized with severe COVID-19 [published online ahead of print March 18, 2020]. N Engl J Med. Doi 10 :.

Cao, X. (2020). COVID-19: immunopathology and its implications for therapy. Nat. Rev. Immunol. 1-2.

CDC (2020). Information for Clinicians on Therapeutic Options for Patients with COVID-19.

Chan, J.F.-W., Choi, G.K.-Y., Tsang, A.K.-L., Tee, K.-M., Lam, H.-Y., Yip, C.C.-Y., et al. (2015). Development and evaluation of novel real-time reverse transcription-PCR assays with locked nucleic acid probes targeting leader sequences of human-pathogenic coronaviruses. J. Clin. Microbiol. 53 : 2722-2726.

Chan, J.F.-W., Lau, S.K.-P., and Woo, P.C.-Y. (2013). The emerging novel Middle East respiratory syndrome coronavirus: the "knowns" and "unknowns". J. Formos. Med. Assoc. 112 : 372-381.

Chan, J.F.-W., Yip, C.C.-Y., To, K.K.-W., Tang, T.H.-C., Wong, S.C.-Y., Leung, K.-H., et al. (2020a). Improved molecular diagnosis of COVID-19 by the novel, highly sensitive and specific COVID-19-RdRp/Hel real-time reverse transcription-polymerase chain reaction assay validated in vitro and with clinical specimens. J. Clin. Microbiol.

Chan, J.F.-W., Yuan, S., Kok, K.-H., To, K.K.-W., Chu, H., Yang, J., et al. (2020b). A familial cluster of pneumonia associated with the 2019 novel coronavirus indicating person-to-person transmission: a study of a family cluster. Lancet 395 : 514-523.

Chen, J.-Y., Qiao, K., Liu, F., Wu, B., Xu, X., Jiao, G.-Q., et al. (2020a). Lung transplantation as therapeutic option in acute respiratory distress syndrome for COVID-19-related pulmonary fibrosis. Chin. Med. J. (Engl).

Chen, L., Xiong, J., Bao, L., and Shi, Y. (2020b). Convalescent plasma as a potential therapy for COVID-19. Lancet Infect. Dis. $20: 398-400$.

Cheng, V.C.C., Lau, S.K.P., Woo, P.C.Y., and Yuen, K.Y. (2007). Severe acute respiratory syndrome coronavirus as an agent of emerging and reemerging infection. Clin. Microbiol. Rev. 20 : 660-694.

ChiCTR (2020). Chinese Clinical Trial Registry.

Chu, C.M., Cheng, V.C.C., Hung, I.F.N., Wong, M.M.L., Chan, K.H., Chan, K.S., et al. (2004). Role of lopinavir/ritonavir in the treatment of SARS: initial virological and clinical findings. Thorax $59: 252-256$.

Chung, M., Bernheim, A., Mei, X., Zhang, N., Huang, M., Zeng, X., et al. (2020). CT imaging features of 2019 novel coronavirus (2019-nCoV). Radiology 295 : 202-207.

Cinatl, J., Morgenstern, B., Bauer, G., Chandra, P., Rabenau, H., and Doerr, H.W. (2003). Treatment of SARS with human interferons. Lancet362 : 293-294.

Clercq, E. De (2019). New Nucleoside Analogues for the Treatment of Hemorrhagic Fever Virus Infections. Chem. Asian J. 14 : 3962-3968.

Clover Biopharmaceuticals (2020). Clover Biopharmaceuticals vaccines programs. Accessed 28 Feb. 2020.

Corman, V.M., Landt, O., Kaiser, M., Molenkamp, R., Meijer, A., Chu, D.K.W., et al. (2020). Detection of 2019 novel coronavirus (2019-nCoV) by real-time RT-PCR. Eurosurveillance 25 :.

Cyranoski, D. (2020). Did pangolins spread the China coronavirus to people. Nature. 
Dai, W., Zhang, B., Su, H., Li, J., Zhao, Y., Xie, X., et al. (2020). Structure-based design of antiviral drug candidates targeting the SARS-CoV-2 main protease. Science (80-. ). eabb4489.

Darwin Malicdem Hydrogen Peroxide A Potential Treatment For Coronavirus Infection?

Debing, Y., Emerson, S.U., Wang, Y., Pan, Q., Balzarini, J., Dallmeier, K., et al. (2014). Ribavirin inhibits in vitro hepatitis $\mathrm{E}$ virus replication through depletion of cellular GTP pools and is moderately synergistic with alpha interferon. Antimicrob. Agents Chemother. 58 : 267-273.

Delamater, P.L., Street, E.J., Leslie, T.F., Yang, Y.T., and Jacobsen, K.H. (2019). Complexity of the basic reproduction number (R0). Emerg. Infect. Dis. 25 : 1 .

Dong, L., Hu, S., and Gao, J. (2020). Discovering drugs to treat coronavirus disease 2019 (COVID-19). Drug Discov. Ther. $14: 58-60$.

DU, H.-Z., HOU, X.-Y., MIAO, Y.-H., HUANG, B.-S., and LIU, D.-H. (2020). Traditional Chinese Medicine: an effective treatment for 2019 novel coronavirus pneumonia (NCP). Chin. J. Nat. Med. 18 : 206-210.

Dyall, J., Coleman, C.M., Hart, B.J., Venkataraman, T., Holbrook, M.R., Kindrachuk, J., et al. (2014). Repurposing of clinically developed drugs for treatment of Middle East respiratory syndrome coronavirus infection. Antimicrob. Agents Chemother. 58 : 4885-4893.

Elshabrawy, H.A., Fan, J., Haddad, C.S., Ratia, K., Broder, C.C., Caffrey, M., et al. (2014). Identification of a broad-spectrum antiviral small molecule against severe acute respiratory syndrome coronavirus and Ebola, Hendra, and Nipah viruses by using a novel high-throughput screening assay. J. Virol. 88 : 4353-4365.

Forster, P., Forster, L., Renfrew, C., and Forster, M. (2020). Phylogenetic network analysis of SARS-CoV-2 genomes. Proc. Natl. Acad. Sci. 202004999.

Fu, Y., Cheng, Y., and Wu, Y. (2020). Understanding SARS-CoV-2-mediated inflammatory responses: from mechanisms to potential therapeutic tools. Virol. Sin. 1-6.

Gadalla, M.R., and Veit, M. (2020). Toward the identification of ZDHHC enzymes required for palmitoylation of viral protein as potential drug targets. Expert Opin. Drug Discov. 15 : 159-177.

Gao, J., Tian, Z., and Yang, X. (2020). Breakthrough: Chloroquine phosphate has shown apparent efficacy in treatment of COVID-19 associated pneumonia in clinical studies. Biosci. Trends.

Gautret, P., Lagier, J.-C., Parola, P., Meddeb, L., Mailhe, M., Doudier, B., et al. (2020). Hydroxychloroquine and azithromycin as a treatment of COVID-19: results of an open-label non-randomized clinical trial. Int. J. Antimicrob. Agents 105949.

Generex (2020). Update:, Generex Provides Coronavirus Develop, Generex Receives Contract from Chinese Partners to Vaccines, a COVID-19 Vaccine Using Ii-Key Peptide.

Genexine (2020). hyFc@ Platform.

Golchin, A., Seyedjafari, E., and Ardeshirylajimi, A. (2020). Mesenchymal Stem Cell Therapy for COVID-19: Present or Future. Stem Cell Rev. Reports 1-7.

Graham, R.L., Donaldson, E.F., and Baric, R.S. (2013). A decade after SARS: strategies for controlling emerging coronaviruses. Nat. Rev. Microbiol. 11 : 836-848.

Grein, J., Ohmagari, N., Shin, D., Diaz, G., Asperges, E., Castagna, A., et al. (2020). Compassionate Use of Remdesivir for Patients with Severe Covid-19. N. Engl. J. Med.

GSK (2020). Clover and GSK announce research collaboration to evaluate coronavirus (COVID-19) vaccine candidate with pandemic adjuvant system.

HHS.gov (2020). Vaccine Types. 
Hodgson, J. (2020). The pandemic pipeline.

Hoehl, S., Rabenau, H., Berger, A., Kortenbusch, M., Cinatl, J., Bojkova, D., et al. (2020). Evidence of SARS-CoV-2 infection in returning travelers from Wuhan, China. N. Engl. J. Med.

Hoffmann, M., Kleine-Weber, H., Schroeder, S., Krüger, N., Herrler, T., Erichsen, S., et al. (2020). SARSCoV-2 cell entry depends on ACE2 and TMPRSS2 and is blocked by a clinically proven protease inhibitor. Cell.

Holshue, M.L., DeBolt, C., Lindquist, S., Lofy, K.H., Wiesman, J., Bruce, H., et al. (2020). First case of 2019 novel coronavirus in the United States. N. Engl. J. Med.

Huang, C., Wang, Y., Li, X., Ren, L., Zhao, J., Hu, Y., et al. (2020). Clinical features of patients infected with 2019 novel coronavirus in Wuhan, China. Lancet 395 : 497-506.

Ibrahim, I.M., Abdelmalek, D.H., Elshahat, M.E., and Elfiky, A.A. (2020). COVID-19 spike-host cell receptor GRP78 binding site prediction. J. Infect.

INOVIO (2020a). dMAb ${ }^{\text {TM }}$ Technology Platform.

INOVIO (2020b). Inovio's Product Pipeline.

INOVIO (2020c). Inovio Accelerates Timeline for COVID-19 DNA Vaccine INO-4800.

Jallouli, M., Galicier, L., Zahr, N., Aumaitre, O., Frances, C., Guern, V. Le, et al. (2015). Determinants of hydroxychloroquine blood concentration variations in systemic lupus erythematosus. Arthritis Rheumatol. $67: 2176-2184$.

Jean, S.-S., Lee, P.-I., and Hsueh, P.-R. (2020). Treatment options for COVID-19: the reality and challenges. J. Microbiol. Immunol. Infect.

Jiang, S. (2020). Don't rush to deploy COVID-19 vaccines and drugs without sufficient safety guarantees.

Jiang, X., Rayner, S., and Luo, M. (2020). Does SARS-CoV-2 has a longer incubation period than SARS and MERS? J. Med. Virol.

Jin, Y., Yang, H., Ji, W., Wu, W., Chen, S., Zhang, W., et al. (2020). Virology, Epidemiology, Pathogenesis, and Control of COVID-19. Viruses 12: 372 .

Kampf, G., Todt, D., Pfaender, S., and Steinmann, E. (2020). Persistence of coronaviruses on inanimate surfaces and its inactivation with biocidal agents. J. Hosp. Infect.

Kang, M.C., Park, H.W., Choi, D.-H., Choi, Y.W., Park, Y., Sung, Y.C., et al. (2017). Plasmacytoid dendritic cells contribute to the protective immunity induced by intranasal treatment with Fc-fused interleukin-7 against lethal influenza virus infection. Immune Netw. 17 : 343-351.

Kanne, J.P. (2020). Chest CT findings in 2019 novel coronavirus (2019-nCoV) infections from Wuhan, China: key points for the radiologist.

Keown, A. (2020). WHO: More than 70 COVID-19 Vaccines are in Development, Three in Clinical Trials.

Khamitov, R.A., Loginova, Si., Shchukina, V.N., Borisevich, S. V, Maksimov, V.A., and Shuster, A.M. (2008). Antiviral activity of arbidol and its derivatives against the pathogen of severe acute respiratory syndrome in the cell cultures. Vopr. Virusol. $53: 9-13$.

Kindrachuk, J., Ork, B., Hart, B.J., Mazur, S., Holbrook, M.R., Frieman, M.B., et al. (2015). Antiviral potential of ERK/MAPK and PI3K/AKT/mTOR signaling modulation for Middle East respiratory syndrome coronavirus infection as identified by temporal kinome analysis. Antimicrob. Agents Chemother. 59 : 1088-1099. 
Kratzel, A., Todt, D., V'kovski, P., Steiner, S., Gultom, M.L., Thao, T.T.N., et al. (2020). Efficient inactivation of SARS-CoV-2 by WHO-recommended hand rub formulations and alcohols. BioRxiv.

Lai, C.-C., Shih, T.-P., Ko, W.-C., Tang, H.-J., and Hsueh, P.-R. (2020). Severe acute respiratory syndrome coronavirus 2 (SARS-CoV-2) and corona virus disease-2019 (COVID-19): the epidemic and the challenges. Int. J. Antimicrob. Agents 105924.

Lan, L., Xu, D., Ye, G., Xia, C., Wang, S., Li, Y., et al. (2020). Positive RT-PCR test results in patients recovered from COVID-19. Jama.

Le, T.T., Andreadakis, Z., Kumar, A., Roman, R.G., Tollefsen, S., \& M.S., et al. The COVID-19 vaccine development landscape.

Lee, J.-H., Cho, J.H., Yeo, J., Lee, S.H., Yang, S.H., Sung, Y.C., et al. (2013). The pharmacology study of a new recombinant TNF receptor-hyFc fusion protein. Biologicals $41: 77-83$.

Lee, N., Chan, K.C.A., Hui, D.S., Ng, E.K.O., Wu, A., Chiu, R.W.K., et al. (2004). Effects of early corticosteroid treatment on plasma SARS-associated Coronavirus RNA concentrations in adult patients. J. Clin. Virol. 31 : 304-309.

Leng, Z., Zhu, R., Hou, W., Feng, Y., Yang, Y., Han, Q., et al. (2020). Transplantation of ACE2mesenchymal stem cells improves the outcome of patients with COVID-19 pneumonia. Aging Dis. 11 : $216-228$.

Li, Q., Guan, X., Wu, P., Wang, X., Zhou, L., Tong, Y., et al. (2020). Early transmission dynamics in Wuhan, China, of novel coronavirus-infected pneumonia. N. Engl. J. Med.

Liu, X., Zhang, M., He, L., and Li, Y. (2012). Chinese herbs combined with Western medicine for severe acute respiratory syndrome (SARS). Cochrane Database Syst. Rev.

Loset, G.A., Roux, K.H., Zhu, P., Michaelsen, T.E., and Sandlie, I. (2004). Differential segmental flexibility and reach dictate the antigen binding mode of chimeric $\operatorname{IgD}$ and IgM: implications for the function of the B cell receptor. J. Immunol. 172 : 2925-2934.

Lu, R., Zhao, X., Li, J., Niu, P., Yang, B., Wu, H., et al. (2020). Genomic characterisation and epidemiology of 2019 novel coronavirus: implications for virus origins and receptor binding. Lancet 395 : 565-574.

Mair-Jenkins, J., Saavedra-Campos, M., Baillie, J.K., Cleary, P., Khaw, F.-M., Lim, W.S., et al. (2015). The effectiveness of convalescent plasma and hyperimmune immunoglobulin for the treatment of severe acute respiratory infections of viral etiology: a systematic review and exploratory meta-analysis. J. Infect. Dis. 211: 80-90.

Metcalf, C.J.E., and Lessler, J. (2017). Opportunities and challenges in modeling emerging infectious diseases. Science (80-. ). 357: 149-152.

MODERNA (2020a). Moderna's Work on a Potential Vaccine Against COVID-19.

MODERNA (2020b). mRNA Platform: Enabling Drug Discovery \& Development.

Morgenstern, B., Michaelis, M., Baer, P.C., Doerr, H.W., and Cinatl Jr, J. (2005). Ribavirin and interferon- $\beta$ synergistically inhibit SARS-associated coronavirus replication in animal and human cell lines. Biochem. Biophys. Res. Commun. 326 : 905-908.

Okba, N.M.A., Raj, V.S., and Haagmans, B.L. (2017). Middle East respiratory syndrome coronavirus vaccines: current status and novel approaches. Curr. Opin. Virol. 23 : 49-58.

Organization, W.H. (2020). Coronavirus disease 2019 (COVID-19): situation report, 67.

Pardi, N., Hogan, M.J., Porter, F.W., and Weissman, D. (2018). mRNA vaccines - a new era in vaccinology. Nat. Rev. Drug Discov. 17: 261. 
Park, A. (2020). Leaked Data From a Key Remdesivir Study Suggest the Potential Coronavirus Drug Is Not Effective.

Peeples, L. (2020). News Feature: Avoiding pitfalls in the pursuit of a COVID-19 vaccine. Proc. Natl. Acad. Sci. 202005456.

Peiris, J.S.M., Lai, S.T., Poon, L.L.M., Guan, Y., Yam, L.Y.C., Lim, W., et al. (2003). Coronavirus as a possible cause of severe acute respiratory syndrome. Lancet $361: 1319-1325$.

Que, T.L., Wong, V.C.W., and Yuen, K.Y. (2003). Treatment of severe acute respiratory syndrome with lopinavir/ritonavir: a multicentre retrospective matched cohort study. Hong Kong Med J 9 : 399-406.

Rice, J., Ottensmeier, C.H., and Stevenson, F.K. (2008). DNA vaccines: precision tools for activating effective immunity against cancer. Nat. Rev. Cancer 8 : 108-120.

Runfeng, L., Yunlong, H., Jicheng, H., Weiqi, P., Qinhai, M., Yongxia, S., et al. (2020). Lianhuaqingwen exerts anti-viral and anti-inflammatory activity against novel coronavirus (SARS-CoV-2). Pharmacol. Res. 104761.

Russell, C.D., Millar, J.E., and Baillie, J.K. (2020). Clinical evidence does not support corticosteroid treatment for 2019-nCoV lung injury. Lancet 395 : 473-475.

Sallard, E., Lescure, F.-X., Yazdanpanah, Y., Mentre, F., and Peiffer-Smadja, N. (2020). Type 1 interferons as a potential treatment against COVID-19. Antiviral Res. 178: 104791.

Samuel, C.E. (2001). Antiviral actions of interferons. Clin. Microbiol. Rev. 14 : 778-809.

Sardesai, N.Y., and Weiner, D.B. (2011). Electroporation delivery of DNA vaccines: prospects for success. Curr. Opin. Immunol. $23: 421-429$.

Savarino, A., Trani, L. Di, Donatelli, I., Cauda, R., and Cassone, A. (2006). New insights into the antiviral effects of chloroquine. Lancet Infect. Dis. $6: 67-69$.

Scagnolari, C., Vicenzi, E., Bellomi, F., Stillitano, M.G., Pinna, D., Poli, G., et al. (2004). Increased sensitivity of SARS-coronavirus to a combination of human type I and type II interferons. Antivir Ther9 : 1003-1011.

Schrezenmeier, E., and Dörner, T. (2020). Mechanisms of action of hydroxychloroquine and chloroquine: implications for rheumatology. Nat. Rev. Rheumatol. 1-12.

Seo, Y.B., Im, S.J., Namkoong, H., Kim, S.W., Choi, Y.W., Kang, M.C., et al. (2014). Crucial roles of interleukin-7 in the development of $\mathrm{T}$ follicular helper cells and in the induction of humoral immunity. J. Virol. $88: 8998-9009$.

Sheahan, T.P., Sims, A.C., Leist, S.R., Schäfer, A., Won, J., Brown, A.J., et al. (2020). Comparative therapeutic efficacy of remdesivir and combination lopinavir, ritonavir, and interferon beta against MERS-CoV. Nat. Commun. $11: 1-14$.

Shen, C., Wang, Z., Zhao, F., Yang, Y., Li, J., Yuan, J., et al. (2020). Treatment of 5 critically ill patients with COVID-19 with convalescent plasma. Jama.

Sheridan, C. (2020). Fast, portable tests come online to curb coronavirus pandemic. Nat. Biotechnol.

So, L.K.Y., Lau, A.C.W., Yam, L.Y.C., Cheung, T.M.T., Poon, E., Yung, R.W.H., et al. (2003). Development of a standard treatment protocol for severe acute respiratory syndrome. Lancet 361 : 1615-1617.

Sohu (2020). Hydrogen molecular biomedicine promotes new coronary pneumonia diagnosis and treatment plan.

Su, H., Yang, M., Wan, C., Yi, L.-X., Tang, F., Zhu, H.-Y., et al. (2020). Renal histopathological analysis of 26 postmortem findings of patients with COVID-19 in China. Kidney Int. 
Sun, J., He, W.-T., Wang, L., Lai, A., Ji, X., Zhai, X., et al. (2020). COVID-19: Epidemiology, Evolution, and Cross-Disciplinary Perspectives. Trends Mol. Med.

Tang, B., Wang, X., Li, Q., Bragazzi, N.L., Tang, S., Xiao, Y., et al. (2020). Estimation of the transmission risk of the 2019-nCoV and its implication for public health interventions. J. Clin. Med. $9: 462$.

Tang, F., Quan, Y., Xin, Z.-T., Wrammert, J., Ma, M.-J., Lv, H., et al. (2011). Lack of peripheral memory B cell responses in recovered patients with severe acute respiratory syndrome: a six-year follow-up study. J. Immunol. 186 : 7264-7268.

Tchesnokov, E.P., Feng, J.Y., Porter, D.P., and Götte, M. (2019). Mechanism of inhibition of Ebola virus RNA-dependent RNA polymerase by remdesivir. Viruses $11: 326$.

Tian, X., Li, C., Huang, A., Xia, S., Lu, S., Shi, Z., et al. (2020). Potent binding of 2019 novel coronavirus spike protein by a SARS coronavirus-specific human monoclonal antibody. Emerg. Microbes Infect. $9: 382-$ 385.

Tilocca, B., Soggiu, A., Sanguinetti, M., Musella, V., Britti, D., Bonizzi, L., et al. (2020). Comparative computational analysis of SARS-CoV-2 nucleocapsid protein epitopes in taxonomically related coronaviruses. Microbes Infect.

Times, T.E. (2020). Chinese research firm attached to Army first to start 2nd clinical trial for coronavirus vaccine.

To, K.K.-W., Tsang, O.T.-Y., Yip, C.C.-Y., Chan, K.-H., Wu, T.-C., Chan, J.M.-C., et al. (2020). Consistent detection of 2019 novel coronavirus in saliva. Clin. Infect. Dis. an Off. Publ. Infect. Dis. Soc. Am.

Touret, F., and Lamballerie, X. de (2020). Of chloroquine and COVID-19. Antiviral Res. 104762.

TW, LeBaron, McCullough ML, R.S.K. A novel functional beverage for COVID-19 and other conditions: Hypothesis and preliminary data, increased blood flow, and wound healing.

University of Queensland (2020). 'Significant step' in COVID-19 vaccine quest.

Vincent, M.J., Bergeron, E., Benjannet, S., Erickson, B.R., Rollin, P.E., Ksiazek, T.G., et al. (2005). Chloroquine is a potent inhibitor of SARS coronavirus infection and spread. Virol. J. $2: 69$.

Walls, A.C., Park, Y.-J., Tortorici, M.A., Wall, A., McGuire, A.T., and Veesler, D. (2020). Structure, function, and antigenicity of the SARS-CoV-2 spike glycoprotein. Cell.

Wan, Y., Shang, J., Graham, R., Baric, R.S., and Li, F. (2020). Receptor recognition by the novel coronavirus from Wuhan: an analysis based on decade-long structural studies of SARS coronavirus. J. Virol.94 :.

Wang, D., Hu, B., Hu, C., Zhu, F., Liu, X., Zhang, J., et al. (2020a). Clinical characteristics of 138 hospitalized patients with 2019 novel coronavirus-infected pneumonia in Wuhan, China. Jama.

Wang, M., Cao, R., Zhang, L., Yang, X., Liu, J., Xu, M., et al. (2020b). Remdesivir and chloroquine effectively inhibit the recently emerged novel coronavirus (2019-nCoV) in vitro. Cell Res. 30 : 269-271.

Wang, Q., Zhang, Y., Wu, L., Niu, S., Song, C., Zhang, Z., et al. (2020c). Structural and Functional Basis of SARS-CoV-2 Entry by Using Human ACE2. Cell.

Wang, Y., Wang, W., Xu, L., Zhou, X., Shokrollahi, E., Felczak, K., et al. (2016). Cross talk between nucleotide synthesis pathways with cellular immunity in constraining hepatitis E virus replication. Antimicrob. Agents Chemother. 60 : 2834-2848.

Wenzel, R.P., and Edmond, M.B. (2003). Managing SARS amidst uncertainty. N. Engl. J. Med. 348 : 19471948.

WHO (2020). Coronavirus (COVID-19) Last updated: 2020/4/26, 2:00am CEST. 
Wilde, A.H. de, Jochmans, D., Posthuma, C.C., Zevenhoven-Dobbe, J.C., Nieuwkoop, S. van, Bestebroer, T.M., et al. (2014). Screening of an FDA-approved compound library identifies four small-molecule inhibitors of Middle East respiratory syndrome coronavirus replication in cell culture. Antimicrob. Agents Chemother. $58: 4875-4884$.

Williams, R. (2020). Are Mesenchymal Stem Cells a Promising Treatment for COVID-19?

Wrapp, D., Wang, N., Corbett, K.S., Goldsmith, J.A., Hsieh, C.-L., Abiona, O., et al. (2020). Cryo-EM structure of the 2019-nCoV spike in the prefusion conformation. Science (80-. ). 367 : 1260-1263.

Wu, C.-Y., Jan, J.-T., Ma, S.-H., Kuo, C.-J., Juan, H.-F., Cheng, Y.-S.E., et al. (2004). Small molecules targeting severe acute respiratory syndrome human coronavirus. Proc. Natl. Acad. Sci.101 : 10012-10017.

Wu, F., Wang, A., Liu, M., Wang, Q., Chen, J., Xia, S., et al. (2020a). Neutralizing antibody responses to SARS-CoV-2 in a COVID-19 recovered patient cohort and their implications. MedRxiv 2020.03.30.20047365.

Wu, F., Zhao, S., Yu, B., Chen, Y.-M., Wang, W., Hu, Y., et al. (2020b). Complete genome characterisation of a novel coronavirus associated with severe human respiratory disease in Wuhan, China. BioRxiv.

Wu, J.T., Leung, K., Bushman, M., Kishore, N., Niehus, R., Salazar, P.M. de, et al. (2020c). Estimating clinical severity of COVID-19 from the transmission dynamics in Wuhan, China. Nat. Med. 1-5.

Xia, J., Tong, J., Liu, M., Shen, Y., and Guo, D. (2020a). Evaluation of coronavirus in tears and conjunctival secretions of patients with SARS-CoV-2 infection. J. Med. Virol.

Xia, S., Liu, M., Wang, C., Xu, W., Lan, Q., Feng, S., et al. (2020b). Inhibition of SARS-CoV-2 (previously 2019-nCoV) infection by a highly potent pan-coronavirus fusion inhibitor targeting its spike protein that harbors a high capacity to mediate membrane fusion. Cell Res. 1-13.

Xiao, F., Tang, M., Zheng, X., Li, C., He, J., Hong, Z., et al. (2020). Evidence for gastrointestinal infection of SARS-CoV-2. MedRxiv.

Xie, X., Zhong, Z., Zhao, W., Zheng, C., Wang, F., and Liu, J. (2020). Chest CT for typical 2019-nCoV pneumonia: relationship to negative RT-PCR testing. Radiology 200343.

Xu, Z., Shi, L., Wang, Y., Zhang, J., Huang, L., Zhang, C., et al. (2020). Pathological findings of COVID-19 associated with acute respiratory distress syndrome. Lancet Respir. Med. 8 : 420-422.

Yamamoto, N., Yang, R., Yoshinaka, Y., Amari, S., Nakano, T., Cinatl, J., et al. (2004). HIV protease inhibitor nelfinavir inhibits replication of SARS-associated coronavirus. Biochem. Biophys. Res. Commun. $318: 719-725$.

Yang, H., Xie, W., Xue, X., Yang, K., Ma, J., Liang, W., et al. (2005). Design of wide-spectrum inhibitors targeting coronavirus main proteases. PLoS Biol. 3 :.

Yang, M. (2020). Cell pyroptosis, a potential pathogenic mechanism of 2019-nCoV infection. Available SSRN 3527420.

Yang, X., Yu, Y., Xu, J., Shu, H., Liu, H., Wu, Y., et al. (2020a). Clinical course and outcomes of critically ill patients with SARS-CoV-2 pneumonia in Wuhan, China: a single-centered, retrospective, observational study. Lancet Respir. Med.

Yang, Y., Islam, M.S., Wang, J., Li, Y., and Chen, X. (2020b). Traditional Chinese Medicine in the Treatment of Patients Infected with 2019-New Coronavirus (SARS-CoV-2): A Review and Perspective. Int. J. Biol. Sci. $16: 1708$.

Yao, X., Ye, F., Zhang, M., Cui, C., Huang, B., Niu, P., et al. (2020). In vitro antiviral activity and projection of optimized dosing design of hydroxychloroquine for the treatment of severe acute respiratory syndrome coronavirus 2 (SARS-CoV-2). Clin. Infect. Dis. 
Yuan, K., Yi, L., Chen, J., Qu, X., Qing, T., Rao, X., et al. (2004). Suppression of SARS-CoV entry by peptides corresponding to heptad regions on spike glycoprotein. Biochem. Biophys. Res. Commun.319 : $746-752$.

Zhang, J., Dong, X., Cao, Y., Yuan, Y., Yang, Y., Yan, Y., et al. (2020a). Clinical characteristics of 140 patients infected by SARS-CoV-2 in Wuhan, China. Allergy.

Zhang, T., Wu, Q., and Zhang, Z. (2020b). Probable pangolin origin of SARS-CoV-2 associated with the COVID-19 outbreak. Curr. Biol.

Zhou, M., Zhang, X., and Qu, J. (2020a). Coronavirus disease 2019 (COVID-19): a clinical update. Front. Med. 1.

Zhou, P., Yang, X.-L., Wang, X.-G., Hu, B., Zhang, L., Zhang, W., et al. (2020b). A pneumonia outbreak associated with a new coronavirus of probable bat origin. Nature $579: 270-273$.

Zhu, N., Zhang, D., Wang, W., Li, X., Yang, B., Song, J., et al. (2020). A novel coronavirus from patients with pneumonia in China, 2019. N. Engl. J. Med.

Zou, X., Chen, K., Zou, J., Han, P., Hao, J., and Han, Z. (2020). Single-cell RNA-seq data analysis on the receptor ACE2 expression reveals the potential risk of different human organs vulnerable to 2019-nCoV infection. Front. Med. 1-8.

Zumla, A., Chan, J.F.W., Azhar, E.I., Hui, D.S.C., and Yuen, K.-Y. (2016). Coronaviruses- drug discovery and therapeutic options. Nat. Rev. Drug Discov. 15 : 327.

Coronavirus (COVID-19) Last updated: 2020/4/23, 2:00am CEST. 